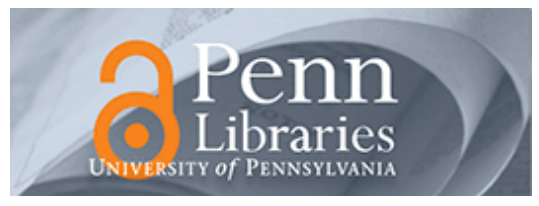

University of Pennsylvania ScholarlyCommons

$1-2003$

\title{
The Structure and Performance Consequences of Equity Grants to Employees of New Economy Firms
}

Christopher D. Ittner

University of Pennsylvania

Richard A. Lambert

University of Pennsylvania

David F. Larcker

Follow this and additional works at: https://repository.upenn.edu/accounting_papers

Part of the Accounting Commons, and the Business Administration, Management, and Operations Commons

\section{Recommended Citation}

Ittner, C. D., Lambert, R. A., \& Larcker, D. F. (2003). The Structure and Performance Consequences of Equity Grants to Employees of New Economy Firms. Journal of Accounting and Economics, 34 (1-3), 89-127. http://dx.doi.org/10.1016/S0165-4101(02)00088-5

This paper is posted at ScholarlyCommons. https://repository.upenn.edu/accounting_papers/34

For more information, please contact repository@pobox.upenn.edu. 


\title{
The Structure and Performance Consequences of Equity Grants to Employees of New Economy Firms
}

\begin{abstract}
The paper examines the determinants and performance consequences of equity grants to senior-level executives, lower-level managers, and non-exempt employees of "new economy" firms. We find that the determinants of equity grants are significantly different in new versus old economy firms. We also find that employee retention objectives, which new economy firms rank as the most important goal of their equity grant programs, have a significant impact on new hire grants, but not subsequent grants. Our exploratory performance tests indicate that lower than expected grants and/or existing holdings of options are associated with poorer performance in subsequent years.
\end{abstract}

\section{Keywords}

management compensation; stock option; incentive

\section{Disciplines}

Accounting | Business Administration, Management, and Operations 


\title{
The Structure and Performance Consequences of Equity Grants to Employees of New Economy Firms
}

\author{
Christopher D. Ittner \\ Richard A. Lambert \\ David F. Larcker \\ The Wharton School \\ University of Pennsylvania \\ Philadelphia, PA 19104-6365
}

Revised January, 2002

This paper can be downloaded from the

Social Science Research Network Electronic Paper Collection:

http://papers.ssrn.com/abstract $=296275$

\begin{abstract}
We would like to thank iQuantic Inc., especially Mark Edwards and Daniel Silver, for providing the compensation data used in this study, as well as many valuable institutional insights. We also thank Robert Bowen, S.P. Kothari, Kevin Murphy, Jerry Zimmerman, and workshop participants at Columbia University, Harvard University, Michigan State University, Northwestern University, the University of Pittsburgh, the Ecole Polytechnique/CIRANO Workshop on Compensation, and the 2001 Journal of Accounting and Economics Conference for their useful comments.
\end{abstract}




\title{
The Structure and Performance Consequences of Equity Grants \\ To Employees of New Economy Firms
}

\begin{abstract}
The paper examines the determinants and performance consequences of equity grants to seniorlevel executives, lower-level managers, and non-exempt employees of "new economy" firms. We find that many of the equity grant determinants and their relative importance vary significantly between new and old economy firms. In addition, we find that employee retention objectives, which new economy firms rank as the most important goal of their equity grant programs, have a significant impact on new hire grants, but not on annual, ongoing grants. Our exploratory performance tests indicate that lower than expected option grants and/or existing option holdings are associated with lower accounting and stock price performance in subsequent years. However, we find that greater than expected option and equity grants and holdings have little consistent association with future performance.
\end{abstract}




\section{The Structure and Performance Consequences of Equity Grants To Employees of New Economy Firms}

\section{Introduction}

Few shifts in the U.S. economy have captured the attention of the business world as much as the emergence and performance of "new economy" firms. ${ }^{1}$ One distinctive feature of these firms is their aggressive reliance on the use of equity grants (stock options and restricted stock) as integral components of their compensation packages for executive and non-executive employees. Relative to more traditional firms, new economy firms provide a larger proportion of compensation in the form of equity grants, have more unexercised stock options as a percent of total shares outstanding, and are more likely to use broadbased stock option programs that cover employees throughout the organization (Anderson, Banker, and Ravindran, 2000; Sesil, Kroumova, Blasi, and Kruse, 2000).

Some observers argue that the extensive use of equity grants by new economy firms has allowed them to improve performance by enhancing the attraction and retention of key employees (particularly in critical technical positions) and by providing superior incentives for employees to enhance shareholder value. Others, however, charge that the large, broad-based equity grants in this sector are excessive and create the potential for excessive dilution of the equity stakes of existing shareholders, promote jobhopping within the industry, provide weak incentives to lower-level employees who have relatively little influence on firm performance, and do little to increase the ability to attract and retain non-executive employees who are motivated more by the characteristics of the job, career opportunities, and other perks than by monetary incentives (e.g., Welles, 1998; Coy, 1999).

This study uses detailed data on the compensation practices of new economy firms to examine three research questions: (1) To what extent are the large equity grants in new economy firms driven by the same economic factors as those driving grants in more traditional firms?; (2) Do the same economic

\footnotetext{
${ }^{1}$ There is not yet a generally agreed upon definition of "new economy" firms. We define new economy firms as organizations competing in the computer, software, internet, telecommunications, or networking fields.
} 
factors explain equity grants across functions and hierarchical levels of new economy firms?; and (3) To what extent are equity grants to employees of new economy firms associated with subsequent firm performance?. We examine these questions using survey data collected by iQuantic Inc. in 1999 and 2000.

In contrast to the primary emphasis on incentive, tax, and cash flow issues in prior compensation studies, the firms in our sample rank employee retention as the most important objective of their equity grant programs. The importance of this objective has a significant positive influence on equity grants to newly hired employees, but is not statistically associated with ongoing equity grants. Our analyses indicate that the relative importance of a number of the hypothesized economic determinants of equity grants vary significantly between new and old economy firms. Moreover, equity grants to executives of new economy firms remain larger than those of "old economy" firms even after controlling for the hypothesized determinants. Equity grants across functions and hierarchical levels within new economy firms appear to be driven by similar economic factors.

Based on these analyses, we develop benchmark models for assessing the relative size of an individual grant (i.e., whether the grant is large or small relative to the grants of similar new economy companies for that hierarchical position or functional area). We use these benchmark results to provide some exploratory insights into the association between equity grants and subsequent accounting and stock market returns. Lower than predicted option grants to chief executive officers (CEOs), directors, and technical employees are associated with lower subsequent accounting return on assets. Similarly, existing option holdings by top executives that are smaller than predicted are associated with lower return on assets and stock price performance following the grant. However, equity grants that are greater than expected have relatively little negative association with future performance, providing no support for claims that the large equity grants by new economy firms adversely impact shareholder value.

The remainder of the paper is organized into four sections. Section 2 develops our research questions. Section 3 provides a description of the sample and variables. Sections 4 and 5 present empirical results on the determinants of equity grants and the association between equity grants and 
performance, respectively. The final section summarizes the results and discusses limitations to our analyses.

\section{Research Questions}

\subsection{Determinants Of Equity Grants}

Although stock options and restricted stock are ubiquitous features of executive compensation contracts in U.S. firms, theoretical work has achieved little success in formally deriving situations under which stock option and restricted stock grants are components of optimal compensation contracts, or in deriving comparative statics results explaining how the usage of options should vary. ${ }^{2}$ Instead, most papers discuss the costs and benefits of equity-based compensation relative to (frequently unspecified) other forms compensation (e.g., Lewellen, Loderer, and Martin (1987), Smith and Watts (1992), Clinch, 1991; Gaver and Gaver, 1993; Yermack (1995), Janakiraman (1998), Core and Guay (1999, 2001), Anderson, Banker, and Ravindran (2000)). These discussions typically emphasize three potential benefits from equity grants: (1) incentive effects, (2) tax savings, and (3) cash flow considerations. A key question is whether the larger equity grants in new economy firms relative to more traditional firms are due to differences in these economic factors.

The incentive effects of equity-based compensation are hypothesized to be related to the following key features of stock option grants: (1) the option's payoff is a convex function of stock price performance, (2) employees must hold options for a non-trivial amount of time before the options vest, (3) employees cannot sell the options, and (4) employees generally must exercise or forfeit their options shortly after leaving the firm. The benefits from each of these features are likely to vary between old and

2 To our knowledge, the only paper that has derived a stock option-based contract as optimal is Innes (1990), where limited liability on the part of the principal and the agent are key features of the environment. Option-like contracts can also be derived from models by appending limited liability constraints (or lower bounds on the contractual payments) to models that derive linear contracts as optimal. For example, Banker and Datar (1988) use the Holmstrom (1979) formulation and derive conditions where the optimal contract is linear over the range of outcomes where the first-order condition on optimal contract applies. If a lower bound on the payments exists, this lower bound will apply to outcomes below some cut-off point (which can be interpreted as the option's exercise price), and the linear contract will apply to outcomes above this exercise price. Many analytical papers derive results where the optimal contract is convex, but do not derive contracts having the piecewise linear structure of stock options (e.g., Holmstrom, 1979, Hemmer, Kim, and Verrecchia, 2000; Core and Qian, 2000). 
new economy firms. For example, the convex shape of the option contract can motivate higher degrees of risk taking (see Rajgopal and Shevlin, 2000, for empirical evidence). ${ }^{3}$ This is likely to be more important in new economy firms that are pursuing unproven, riskier strategies. ${ }^{4}$ The availability and quality of performance measures other than stock price also varies with the growth opportunities and life cycle of the firm (e.g., Clinch, 1991; Smith and Watts, 1992; Gaver and Gaver, 1993). In young firms, firms in the early stages of product development, high growth firms, and firms undertaking extensive research and development or investment in "intangible" assets, accounting measures do not reflect all of the anticipated future period consequences associated with decisions being made today, even though the investments in $R \& D$, brand name, customer satisfaction, and other intangible assets are expensed the period they are incurred. Therefore, new economy firms in these situations are expected to base incentives on more forward-looking stock price measures rather than accounting measures in order to increase the performance measures' informativeness and lengthen the decision-making horizon of employees.

Prior research also suggests that cash constraints and tax implications should lead to greater use of equity grants by new economy firms. In contrast to salary and most forms of annual bonus, compensating employees using stock options does not require a current outlay of cash by the firm. As a result, firms experiencing cash flow difficulties (such as those in early stages of their product life cycle) are expected to make greater use of options to conserve cash (e.g., Yermack, 1995; Core and Guay, 1999, 2001). ${ }^{5}$ Options granted at the money are not taxed to the employee or deductible to the firm at the time

\footnotetext{
${ }^{3}$ In contrast, analytical work by Lambert, Larcker, and Verrecchia (1991) shows that if executives are risk averse and undiversified, options which are expected to finish far in the money can motivate executives to become more risk averse, rather than less.

${ }^{4}$ Prendergast (2000) provides additional reasons for a positive link between risk and incentives that emphasize the increased use of incentives to compensate for the difficulty in monitoring in uncertain environments. While these arguments suggests option use may be greater in riskier firms such as those operating in the new economy, there is a countervailing force. Agency theory suggest that incentive based pay will decrease, ceteris paribus, the noisier the performance measure, because it is costly to the firm to impose compensation risk on a risk averse employee. Thus, the use of option grants may actually be lower in riskier firms.

${ }^{5}$ This argument implies that firms are using employees to help finance the firm. It is not clear why employees would allow the firm to use them as an inexpensive source of financing. One possibility (an extreme version of the sorting argument discussed below) is that options attract employees who are risk seeking. For example, some
} 
of the grant, although they can have tax effects later (depending on the type of option). These tax rules lead Yermack (1995) and Core and Guay $(1999,2001)$ to argue that firms should use more stock options in periods when current tax rates are low, which is more likely in less profitable new economy firms than in more traditional companies.

Two potential benefits of equity-based compensation that have received relatively little attention in prior empirical studies are improving the attraction and retention of key employees. These two benefits are viewed by many to be particularly important in new economy firms, which faced tight labor markets for key technical personnel at the time the data in our study were collected (e.g., Battey, 2000, Portnot and Moltzen, 2000). From a theoretical standpoint, if the objective is merely to attract workers, the level of compensation should be important, not the form of the compensation. The importance of equity-based incentives as an attraction device must therefore be related to attracting the right "type" of employee. In particular, options can play a screening or sorting role because some types of employees will find option-based contracts more attractive than will other types. ${ }^{6}$ For example, option-based contracts are more attractive to employees who are less risk averse. This is likely to be a more important benefit to firms operating in high-risk environments such as the new economy, where many firms are pursuing untested products, markets, and business models. Option-based contracts are also more attractive to employees with higher skill levels who have greater ability to take actions that cause their options to finish in the money. The sorting role is most beneficial in situations where the impact of skill

employees may view taking a job at a new economy start-up like playing the lottery. If the current job does not work out, they can easily move to another start-up company or take a position with a more traditional firm (a possibility that was probably more realistic during the period covered by our survey than it is today). It is also possible that employees perceive the firm's risk differently than financial institutions. For example, employees in key functional areas may have technical knowledge and familiarity with the firm's projects and strategies that cannot be credibly conveyed to an outside financial institution. Finally, employees may not be able to understand the risks they are taking on, either in terms of compensation risk or employment risk. For example, they may be more optimistic about the firm's future prospects than an outside "objective" observer.

${ }^{6}$ In many respects, the role of the contract in sorting employees by talent is similar to that of motivating effort. Hagerty and Siegel (1992), for example, establish conditions where moral hazard models and adverse selection models can be represented in identical fashions. However, the sorting role is likely to be more important for newly hired employees. 
on the firm's stock price is highest, such as firms with considerable intangible assets and growth opportunities (Core and Qian, 2000).

Stock options (as well as restricted stock) also motivate employees to remain with the firm because of vesting periods that require employees to remain with the firm for a period of time (generally one to four years) before they can exercise their options, and because option contracts generally impose a "penalty" on the employee for leaving (i.e., the employee must exercise his vested options early). Retention becomes more valuable to the firm when employees can take information, know-how, or technology with them that can be used by competitors, a problem that is compounded when the employee's cost of changing jobs is low. The latter benefit is likely to be a function of the concentration of related jobs in the region, the demand for certain professions, and the amount of firm-specific human capital required, each of which was quite high in the new economy labor market during this period (Battey, 2000).

If the same economic model linking the preceding features to equity grants applies to both new and old economy firms, the level of equity grants in the two sectors should be similar after controlling for these features. In contrast, discussions in the business press and academic literature suggest that the same economic model of equity grant behavior does not apply to both sectors. Articles by Brandal (2000) and Portnot and Moltzen (2000), for example, suggest that equity grants in new economy firms reflect significantly different economic priorities or a completely different set of factors that are not yet in equilibrium (e.g., imitating competitors because optimal practices in this rapidly-evolving industrial sector are not yet known). Research by Anderson, Banker, and Ravindran (2000) finds that information technology firms and firms in the Silicon Valley make larger equity grants than more traditional firms even after controlling for the traditional economic determinants used in prior empirical research. However, their study assumes that the economic model linking equity grants to their hypothesized determinants is the same for all firms, and does not allow the coefficients to vary across sectors. Balkin, Markman, and Gomez-Mejia (2000) find that long-term, equity-based CEO compensation is related to the level of innovations (R\&D spending and number of patents) in high technology manufacturers, but not in 
other manufacturers. Their results suggest that the influence of this economic characteristic on equitybased compensation is quite different in the two sectors, but the inferences from their tests are limited by the exclusion of other potential economic determinants. The inconclusive results in these studies lead to our first research question:

To what extent are the large equity grants in new economy firms driven by the same economic factors as those driving grants in more traditional firms?

\subsection{Equity Grant Determinants Across Hierarchical Levels and Functions}

Most prior stock option studies focus on the determinants of option grants to executives. ${ }^{7}$ Yet one of the distinctive features of new economy firms is their widespread use of broad-based stock option plans that cover employees throughout the company (Pepe, 1998). Although most incentive contracting models are general enough to cover any level or function, the relative importance of different economic factors in determining equity grants can vary due to issues such differences in risk aversion and ability to influence firm performance. For example, employees must be in a position to impact stock price through their actions for stock options to be an effective means of providing incentives. However, individuals at lower hierarchical levels have less ability than executives to impact stock price through their actions, reducing the benefits from broad based equity grant programs. The ability to impact stock price is also likely to differ across functional areas. For example, in many new economy firms, the development of new technology is an important driver of success. Therefore, employees working in technical areas (such as engineering, information technology, and research and development) have a stronger ability to impact stock price in these firms, leading to greater use of stock options in these functions.

Theory also suggests that information asymmetries play a role in the design of incentive contracts. When managers are privately informed about the profitability of investments, incentive-based contracts

\footnotetext{
${ }^{7}$ Exceptions include Holthausen, Larcker, and Sloan (1995), who examine business unit managers, and Core and Guay (2001), who investigate non-executive employees (defined as all employees other than the top five executives in the firm).
} 
are useful even if the employees' actions are observed. ${ }^{8}$ In particular, the convex shape of option contracts motivates managers to tailor the aggressiveness of their investment as a function of how profitable their private information indicates the investment will be (Core and Quian, 2000). The degree of information asymmetry between employees and shareholders is likely to be higher in highly technical functions than in other functions within the firm.

Finally, the availability and quality of performance measures other than stock price varies across functions. For example, in sales and marketing functions, commission-based incentives provide a more direct link between actions and outcomes, while in production areas operational performance measures often provide an effective means of providing incentives. In contrast, it is more difficult to directly measure performance in situations where there is a significant amount of private information possessed by the employees. Therefore, in more technical areas, a greater proportion of incentives is likely to come via options. These issues lead to our second research question:

Do the same economic factors explain equity grants across functions and hierarchical levels of new economy firms?

\subsection{Evidence on Performance Consequences of Equity Grants}

Perhaps the most complex question raised by the large equity grants by new economy firms is their performance consequences. This issue has generated considerable controversy, with proponents arguing that the large grants are necessary for attracting, retaining, and motivating the appropriate type of employee and opponents charging that the grants are excessive (e.g., Welles, 1998; Coy, 1999). Yet, despite the large body of research on equity-based compensation, empirical evidence on the performance consequences of equity grants is limited and mixed. Abowd (1990) examines the relation between the sensitivity of compensation (salary and bonus) to total shareholder returns and stock returns in the following year. He finds a positive relation, but does not directly examine the performance benefits from equity grants. DeFusco, Johnson, and Zorn (1990) find the approval of executive stock option plans

\footnotetext{
${ }^{8}$ This occurs because the principal is unable to determine whether the correct action has been taken given the manager's private information. See Lambert (1986) and Baker (1992) for further analysis.
} 
accompanied by significant positive stock market and negative bond market reactions. Their study does not examine ongoing equity grants or their magnitudes. Anderson, Banker, and Ravindran (2000) estimate a simultaneous equations model linking executive bonuses, stock option grants, and contemporaneous stock returns. They find significant positive simultaneous relations between annual option grants and same period stock returns, and conclude that the extent of incentive pay positively affects performance. However, the use of contemporaneous stock returns makes it difficult to determine whether the option grants were rewards for performance during the year or whether they induced superior performance.

Value relevance studies also provide conflicting results. Aboody (1996) finds a negative association between the value of all outstanding employee stock options and share prices for a broad set of firms. Bell, Landsman, Miller, and Yeh (2000) and Keating, Lys, and Magee (2001), on the other hand, find positive association between employee stock options and market value in computer software firms and internet firms, respectively.

Conyon and Freeman (2000) look at broad-based stock option plans covering employees throughout the company, and find the presence of a company share option plan associated with significantly higher productivity. Similarly, Sesil, Kroumova, Kruse, and Blasi (2000) find significant, positive associations between the presence of broad-based option plans and productivity, sales growth, and Tobin's Q, but no association with total shareholder returns. A related study of new economy firms (Sesil, Kroumova, Blasi, and Kruse, 2000) indicates that firms with broad-based stock option plans had higher labor productivity, Tobin's Q, and patent levels than new economy firms without such plans, but finds little evidence that performance changes differed in the two groups. Moreover, total shareholder returns were somewhat lower in the stock option group than in a matched sample of new economy firms without these plans. A major limitation to these three studies is the use of simple dichotomous variables to indicate the presence of broad-based stock option plans, and the lack of data on what organizational levels or functions received the options or the magnitude of the grants. 
The limited and inconclusive evidence on the performance consequences of equity grants leads to our third research question:

To what extent are equity grants to employees of new economy firms associated with subsequent firm performance?

We consider this research question to be crucially important for understanding observed compensation contract designs. However, we acknowledge that the endogeneity of equity grants (discussed more fully in Section 5.1) and the difficulty in constructing well-specified tests for detecting performance differences limit our ability to assess the performance consequences of equity grants. Thus, we view this research question as exploratory and speculative.

\section{Data and Variables}

\subsection{Sample}

Our data are obtained from detailed mail surveys of new economy firms conducted by iQuantic Inc. during 1999 and 2000, with the surveys covering equity grants made during fiscal 1998 and 1999, respectively. ${ }^{9}$ Our sample consists of 217 unique firms. ${ }^{10}$ Personal correspondence with iQuantic management indicates that less than $20 \%$ of the sample purchased consulting services of some kind from iQuantic during the calendar year of data collection. Similar to all studies using proprietary data collected by consulting firms, our sample is likely to exhibit some selection bias, which will limit our ability to generalize our results. However, since the incidence of iQuantic consulting for the sample is modest, we believe that our data provide general insights into compensation plan design choices and do not simply reveal the consulting recommendations made to these firms by iQuantic.

As shown in Table 1, the majority of respondents are located in the western United States, with another large cluster on the east coast (Panel A). The sample spans a variety of industrial sectors

\footnotetext{
${ }^{9}$ iQuantic Inc. is a human resource consulting firm headquartered in San Francisco that focuses on new economy firms. The survey questionnaires are sent out in January and the data are collected in March.

${ }^{10}$ There is some overlap in firms contained in the two surveys. We retain only one observation per firm by deleting responses to the 2000 survey for firms in both the 1999 and 2000 surveys.
} 
associated with the new economy, with the largest membership in the software and semiconductor sectors (Panel B). The firms are relatively young, with the median initial public offering completed approximately seven years ago (Panel C). The typical respondent is relatively small, with a median market capitalization of $\$ 1,137$ million, sales of $\$ 244$ million, and 1,130 employees.

One attribute of this sample is the limited use of compensation components such as annual bonuses and performance plans that are commonly found in traditional firms. For example, iQuantic (1999) finds that $99 \%$ of the firms in their survey have an annual bonus, but the annual bonus payoff only ranges between six and nine percent of the total compensation paid to executives. Similarly, performance shares $(11 \%$ of the firms) and performance units ( $5 \%$ of the firms) are used infrequently, and the dollar magnitudes of these grants are very small. Thus, we can restrict our focus to equity grants (stock options and restricted stock) and annual salary, without introducing serious measurement error into our metrics. ${ }^{11}$

\subsection{Descriptive Statistics for Equity Programs}

As shown in Table 2, the survey respondents report a variety of objectives for their stock option and restricted stock programs. The scores in Table 2 were computed from the respondent ranking assigned to each of the objectives, where a rank of one was assigned to the most important objective and unranked objectives were assigned a rank one higher than the last objective ranked by the respondent (e.g., if the respondent ranked four out of the seven objectives, the unranked objectives were assigned a rank of five). The ranks for a specific objective were then transformed into a scale score ranging from zero to 100 (where the score $=100 \times$ (maximum rank across all objectives - rank of a specific objective)/(maximum rank across all objectives - minimum rank across all objectives )). The objective with the highest ranking was assigned a score of 100 and the score for the lowest ranked or unranked objective was assigned a score of zero.

\footnotetext{
${ }^{11}$ For employees in sales and marketing, commissions are included as part of the salary figures collected by iQuantic. Virtually all the restricted stock grants in our sample are to employees at the vice-president level or higher. Therefore, nearly all of the equity incentives for lower level employees are in the form of stock options.
} 
Two of the primary motivations for implementing these programs are retaining existing employees and attracting new employees (i.e., labor market considerations). Other key objectives for stock options are rewarding the completion of specific milestones or goals and linking the individual to company performance (i.e., incentive issues), while providing competitive total compensation is an important motivation for granting restricted stock (a labor market consideration that is likely to be related to attraction and retention of employees). Interestingly, using equity grants to encourage stock ownership is of lesser importance.

CEOs are eligible for the equity grant programs in $97.9 \%$ of the firms, vice presidents in $99.7 \%$, directors in $98.0 \%$, managers in $94.5 \%$, individual contributors in $86.8 \%$, non-exempt employees in $61.1 \%$, technical employees in $94.4 \%$, non-technical employees in $92.4 \%$, and sales personnel in $90.6 \%{ }^{12}$ The typical frequency of option grants is annual $(88.7 \%$ grant annually and $8.5 \%$ grant semi-annually or more frequently), with the majority of options having an exercise price equal to the fair market value of the stock at the date of grant. Approximately $40 \%$ of our firms have the authority to grant restricted stock, with $20.7 \%$ granting restricted stock during the time period covered by the survey.

\subsection{Equity Grant Measures}

We examine the value of grants to employees at different positions and in different functional areas. The data represent either the grant guideline (or target) for the number of stock options and restricted stock at a specific salary level for a position, or (when the guideline is not available) the average actual stock options and restricted shares granted at a specific salary level within a position. ${ }^{13}$ These positions include senior executives (chief executive officer and vice-presidents), directors (technical and non-technical functions), managers (technical, non-technical, and sales functions), individual contributors

\footnotetext{
${ }^{12} \mathrm{CEO}$ actually participate in the plans in $85.2 \%$ of the firms, vice presidents in $89.5 \%$, directors in $83.6 \%$, managers in $71.5 \%$, individual contributors in $50.9 \%$, non-exempt employees in $27.8 \%$, technical employees in $71.0 \%$, non-technical employees in $67.0 \%$, and sales personnel in $61.2 \%$.

${ }^{13}$ Approximately $65 \%$ of the firms use formal guidelines or targets for grants across the positions. In addition, approximately $85 \%$ to $90 \%$ of the actual grants for each position are within $10 \%$ of the guideline or target. Thus, the guideline data are quite close to the actual grants of stock options and restricted stock.
} 
(technical, non-technical, and sales positions), and non-exempt employees. ${ }^{14}$ Functional areas include technical, non-technical, and sales operations. Thus, our equity grant data correspond to the representative or typical payment for a specific employee position.

We sum the value of options and restricted stock to measure the annual equity grant for the various positions and functions. Consistent with most studies, restricted stock is valued by multiplying the number of shares by the fair market value of a share at the date of grant. iQuantic values stock options using the discounted expected gain approach, with an assumed annual stock price growth of $15 \%$, a five year holding period before the option is exercised, and a risk-free rate of $5 \%$. Although a relatively unsophisticated approach for valuing option grants, analytical studies question whether more sophisticated methods such as the Black-Scholes model are applicable to the valuation of stock options for employees (e.g., Lambert, Larcker, and Verrecchia, 1991). Moreover, most firms use very simple approaches to value their option grants and to communicate option plans with employees. Specifically, the Black-Scholes model is used for these purposes by only $22.5 \%$ of the firms in our sample, whereas $23.5 \%$ use the present value of the expected gain, $18.0 \%$ use the strike price multiplied by the number of options granted, $32.0 \%$ do not use any type of valuation model, and $4.0 \%$ use some other valuation approach. $^{15}$

To develop a parsimonious measure of equity intensity, we divide the average equity grant value for each position (computed using the method above) by average equity grant value plus the average

\footnotetext{
${ }^{14}$ The vice president level includes all corporate officers except the CEO (i.e., chief operating officer, chief financial officer, and chief information officer), senior vice-presidents, vice presidents, and assistant vice presidents. Individual contributors are non-managerial, exempt employees. Technical employees develop, research, and provide high-level technical support for the company's products. Non-technical employees are neither technical nor part of sales, and include, among others, finance, legal, human resources, and customer service.

${ }^{15}$ The approach used for valuing stock options is somewhat primitive because it will value each stock option at approximately $79 \%$ of the exercise price. Although, as discussed in the text, the use of Black-Scholes is theoretically problematic, we repeated the subsequent analyses using Black-Scholes methods. As expected given the differences in volatility (Table 4), the mean value of option grants using Black-Scholes was $55 \%$ of the exercise price for new economy firms and $38 \%$ for old economy firms. However, our results were not substantively affected by using the Black-Scholes valuation approach. In particular, variables that are statistically significant in Table 6 remained significant, while those that were not significant remained insignificant. The primary changes related to the comparisons between new and old economy firms in Table 6 , which were much more pronounced in terms of coefficient differences and significance levels.
} 
salary for the position. The resulting measure (\%EQUITY GRANT) represents the percentage of total compensation that is equity-based. Statistics for the technical functions are the average compensation figures for technical employees at the director, manager, and individual contributor levels. Similar computations are made for non-technical functions. Sales function measures are the average compensation for manager and individual contributor levels.

Descriptive statistics for the value of equity grants, salary, and the equity grant percentage are presented in Table 3. ${ }^{16}$ Consistent with prior research (e.g., Lambert, Larcker, and Weigelt, 1993), salary levels and the value of equity grants monotonically decrease down the organizational hierarchy. The median CEO's compensation is $86.9 \%$ equity-based, while the median non-exempt employee receives $10.8 \%$ of compensation in the form of equity grants. Salary levels across functional areas are quite similar, with technical employees having slightly higher equity grant values and equity grants as a percent of compensation.

\subsection{Determinants of Equity Grant Intensity}

\subsubsection{Incentive Measures}

Our first set of predictor variables attempts to capture the hypothesized incentive-related determinants of equity grants in new economy firms.

Investment Opportunity Set. Similar to Gaver and Gaver (1993) and Baber, Janakiraman, and Kang (1996), we use multiple indicators to measure the firm's investment opportunity set. These indicators are the ratio of book value to market value (an inverse measure of investment opportunities), the ratio of research and development expenditures to sales, the advertising to sales ratio, sales growth in the prior year, and the natural logarithm of firm age (defined as the number of years since the firm's

\footnotetext{
${ }^{16}$ In order to mitigate the impact of extreme observations for this somewhat unusual set of firms, equity grant values and predictor variables are winsorized at the $2.5 \%$ and $97.5 \%$ levels of the observed distributions.
} 
initial public offering, with younger firms assumed to have larger growth opportunities). ${ }^{17}$ The results of a principal component analysis reveal that the five indicators load on a single factor that retains 48 percent of the variation in the data. The Cronbach alpha for the indicators is 0.64 , indicating adequate internal consistency among the measures (i.e., the five indicators of this construct exhibit substantial positive bivariate correlations). The latent variable InvestOppSet represents the average standardized value of these five variables. ${ }^{18}$ Consistent with prior studies, we predict a positive association between the investment opportunity set and equity grants.

Past Performance. Three variables measure elements of past performance that are expected to influence equity grants. Stock market performance is measured using the average continuously compounded monthly return over the 12 -months prior to the start of the fiscal year associated with the equity grant (Prior Return). For example, the 1999 survey collected data for grants that typically were made at the end of 1997 or beginning of 1998 . Thus, this variable is measured over the time period from January 1997 to December 1997 for a company with a December fiscal year end that was included in the 1999 survey. We use prior pretax income divided by total assets (Return on Assets) measured over a similar period as an alternative measure of past performance. If equity grants are used to reward past performance, they should be positively associated with past accounting and market performance.

We also examine the volatility (standard deviation) of stock returns over the prior year (Volatility). The compensation literature provides conflicting hypotheses regarding the relation between equity grants and stock price volatility. One argument is that high volatility makes stock price a noisy indicator of employee performance, and therefore imposes more risk on the employee. This view suggests that fewer equity grants will be used in high variance firms. A counter-argument is that the

\footnotetext{
${ }^{17}$ For cases where research and development or advertising was missing, we imputed a value of zero for these variables.

${ }^{18}$ The book-to-market ratio and firm age are reverse coded in this computation. We use an equal weighting of the standardized indicators rather than using the principal component weights or loadings to compute InvestOppSet. This is consistent with the recommendations of Grice and Harris (1998), who find that unit-weighted composites exhibit better psychometric properties than factor scores.
} 
convex shape of stock options makes them more valuable to employees when volatility is high. The latter view suggests that stock price volatility and equity grants should be positively correlated.

Firm Size. We measure firm size using the natural logarithm of the number of employees. Prior studies provide conflicting hypotheses regarding the relation between the use of equity grants and firm size. One hypothesis suggests that it is more difficult to monitor managers in larger firms, and thus there is more need to use options as an incentive device. An alternative hypothesis suggests that options will be used less in larger firms because it is more difficult for individual employees to affect firm value. Given the conflicting implications of these hypotheses, the predicted relation between equity grants and number of employees is unclear.

Alternative Monitoring Mechanisms. Corporate governance mechanisms provide an alternative to the explicit use of equity-based incentives. For example, holders of large blocks of stock have greater incentive to monitor the actions of managers and greater power to force managers to allow monitoring to occur (e.g., Engel, Gordon, and Hayes, 2001). Similarly, bondholders have incentives to restrict managers' ability to take actions that transfer wealth from bondholders to shareholders and/or managers (Yermack, 1995). Consequently, the use of equity-based incentives should be lower when external monitoring is greater.

We use three proxies for alternative monitoring mechanisms. Monitoring by external shareholders (e.g., venture capitalists and institutional investors) is measured using the number of five percent blockholders (excluding firm executives) and the percentage of shares held by outside blockholders. These variables are obtained from the firms' proxy statements, and are denoted Num Blockholders and Block Ownership Pct, respectively. Firm leverage, a proxy for monitoring by debt holders, is measured as the ratio of long-term debt to total assets (Leverage). Block Ownership Pct and Leverage are expected to be negatively related to equity grants. The predicted sign for Num Blockholders is less certain. To the extent that each of the large stockholders can monitor employees, the relation with equity grants should be negative. However, holding the total extent of large external holdings constant 
(i.e., Block Ownership Pct), larger number of blockholders can lead to more diffuse and less effective monitoring, suggesting a positive relation.

\subsubsection{Attraction and Retention Measures}

Core and Guay (2001) predict that the firm's investment opportunity set is likely to be associated not only with the use of stock options for incentive purposes, but also with their use for attracting and retaining employees. This prediction is based on work suggesting that firms with substantial, and potentially risky, growth opportunities require higher quality managers and less risk-averse employees who are more likely to be attracted to equity-based compensation (e.g., Smith and Watts, 1992; Core and Qian, 2000). In addition, we employ several additional variables to capture the importance of employee attraction and retention.

Growth in Employees. We include the percentage growth in employees in the prior year (Employee Growth) as a predictor variable under the assumption that attraction and retention issues are more important when firms are rapidly expanding their workforce. If rapidly growing firms are using equity grants to attract and retain the appropriate type of employee, employee growth should be positively associated with equity grants.

Program Objectives. As discussed above, respondents to the iQuantic survey were asked to rank the relative importance of various objectives for their equity grant programs. The variables Attraction Objective and Retention Objective represent the self-reported importance of these two program objectives. Academic researchers and the business press suggest that these objectives are positively associated with the use of equity grants in new economy firms.

Regional Indicators. We include two regional indicator variables to control for potential labor market differences that could affect the use of equity grants for attraction and retention. The two 
indicators represent the west coast (primarily the Silicon Valley) and east coast (primarily New England), regions that reportedly experienced considerable competition for technical employees during this period.

\subsubsection{Other Determinants}

We include several variables to capture other potential determinants of equity grants.

Tax Rates. Similar to Plesko (1999) and Core and Guay (2001), we measure the marginal tax rate using two indicator variables. Low marginal tax rate firms are assumed to have negative pretax book income and net operating loss carry-forwards. Low Tax equals one for firms that satisfy these restrictions, and zero otherwise. High marginal tax rate firms are defined as those with have positive pretax book income and no net operating loss carry-forwards. High Tax equals one for firms that satisfy these restrictions, and zero otherwise. ${ }^{19}$ Equity grants are expected to be negatively associated with the high tax indicator and positively associated with the low tax indicator.

Cash Flow. Two variables are used to measure the amount of cash available for compensation payments. The first variable captures the net cash flow from operating activities minus cash dividends, capital expenditures, and research and development expenditures. We divide the level of cash flow by the number of employees (Cash Flow/Employee) to assess the ability of the firm to pay employees using cash compensation. The second variable (Cash Level/Employee) proxies for the level of cash available for compensation purposes. This variable equals cash plus marketable securities minus current liabilities,

\footnotetext{
${ }^{19}$ Graham (2000) outlines a more sophisticated strategy for estimating a firm's marginal tax rate by incorporating a greater number of features of the tax code and by calculating expected tax benefits by forecasting possible scenarios for future income. Unfortunately, Graham's tax rates are not available for a large number of firms in our sample. Another problem in estimating the marginal tax rate of our firms (that neither the Graham nor Plesko procedures incorporate) relates to the accounting treatment of the tax benefits of stock options. In particular, the deduction firms receive for nonqualified stock options in the year of exercise is not accounted for as a deduction from the firm's income tax expense. Instead, it is treated as a credit to additional paid-in-capital and a debit to income taxes payable liability account. Therefore, the current portion of the firm's income tax expense overstates the actual taxes due on the firm's current taxable income. See Hanlon and Shevlin (2001) for additional discussion and analysis.
} 
divided by the number of employees. If cash constrained firms are using equity grants in place of cash compensation, the coefficient on these variables should be negative.

Survey Year. Since we are pooling across two survey years, we include an indicator variable for surveys conducted in 2000 (YR2000) to control for differences between the 1999 and 2000 survey periods.

\subsection{Comparison to Old Economy Firms}

Table 4 provides a comparison of equity grants and their hypothesized determinants for our new economy sample and a sample of "old economy" firms. The old economy sample consists of traditional durable and nondurable manufacturers, which many commentators claim are the epitome of the old economy (e.g., Balkin, Markman, and Gomez-Mejia, 2000). We begin selecting the old economy sample using all manufacturers in Execucomp with available data for fiscal years 1998 and 1999. We then eliminate all firms that also appear in our new economy sample and all four-digit SIC codes with three or more observations in the iQuantic survey. To ensure comparability between the samples, the equity grant values for the old economy firms are computed using the same methods as those for the new economy firms. Equity grants for lower-level employees and institutional blockholdings are not available from Compustat or Execucomp, and are not included in the table.

The two samples exhibit significant differences on nearly every dimension. The mean (median) CEO in a new economy firm receives $78.2 \%(86.9 \%$ ) of compensation from equity grants, versus $26.9 \%$ $(19.3 \%)$ in an old economy firm. Equity grants to vice presidents show similar differences. As expected, new economy firms have lower book to market ratios, larger research and development expenditures relative to sales, and faster growth in sales and employees. ${ }^{20}$ New economy firms also have substantially

\footnotetext{
${ }^{20}$ The mean (median) market-to-book ratios for our new economy sample are $12.1(6.7)$ for firms in the 2000 survey and 7.7 (3.65) for firms in the 1999 survey. Note that the mean market-to-book ratio is not simply the inverse of the mean book-to-market ratio because the ratios have highly skewed distributions and because some of the observations have negative values for book value. The second reason also explains why the median value of the market-to-book ratio is not simply the inverse of the median book-to-market ratio.
} 
larger cash holdings available for compensation, but the mean level of cash flow available for compensation payments is substantially more negative. Consistent with results in the corporate finance literature on firms with large levels of intangible assets, the new economy sample uses a relatively small amount of leverage for financing purposes. Although prior stock returns are not statistically different, the typical new economy firm has larger monthly stock price volatility and lower return on assets, and is less likely to fall in the high tax bracket.

\section{Determinants of Equity Grants}

\subsection{Executive Equity Grants in New Economy Firms}

We begin our analysis by examining the determinants of equity grants to CEOs and vice presidents of new economy firms. The results are reported in Table $5 .^{21}$ The models explain a substantial proportion of equity grants to these executives, with adjusted $\mathrm{R}^{2} \mathrm{~s}$ of 0.557 in the CEO model and 0.375 in the vice president model. Many of the significant relations are similar to those found in studies of traditional firms. As predicted, the coefficient on investment opportunity set is positive and significant in both tests. Larger firms also tend to grant more equity as a percent of compensation than smaller firms. The outside monitoring variables exhibit mixed statistical associations with equity grants. Consistent with prior studies, leverage is negative and significant in the CEO model, supporting claims that monitoring by debt holders is a substitute for equity-based incentives. Similarly, block ownership percentage is negatively associated with equity grants to vice presidents. However, the number of five percent blockholders has a significant positive association with grants to vice presidents, suggesting that more dispersed institutional holdings encourage greater use of equity incentives, after controlling for the total percentage of shares held by blockholders.

The attraction and retention proxies show mixed results. Retention objectives are positive and significant ( $\mathrm{p}<0.01$, two-tailed) in the CEO model, consistent with claims that retention is an important

\footnotetext{
${ }^{21}$ Observations are deleted from all of our regression estimations if the absolute values of their studentized residual are greater than three. Variance Inflation Factor (VIF) scores indicate no serious problems with multicollinearity in any of our regression models.
} 
determinant of equity grants in new economy firms. However, attraction objectives are not significant in this model. Moreover, employee growth is negatively related to CEO grants, opposite our prediction. None of the attraction and retention proxies is significant in the vice president model. These results provide relatively little support for claims that attraction and retention objectives are important drivers of equity-based compensation in new economy firms.

In contrast to studies of traditional firms (e.g., Core and Guay, 1999, 2001), we find no evidence that cash constrained new economy firms make greater use of equity-based compensation to conserve cash. In fact, the coefficients on Cash Flow/Employee and Cash Level/Employee are both positive and significant in the CEO model, as is the coefficient on Cash Level/Employee in the vice president model. Thus, new economy firms with larger cash reserves tend to make greater use of equity grants than those with cash constraints. ${ }^{22}$

The effects of taxes and past performance on equity grants to executives are limited. High Tax has the predicted negative relation in the CEO model, but is not significant in the vice president model. Low Tax, Volatility, Prior Return, and Prior ROA are not significant at the ten percent level (two-tailed) in either model, even though a number of studies of equity grants in traditional firms have found these variables to be significant predictors. ${ }^{23}$

\footnotetext{
${ }^{22}$ These results are robust to scaling our cash variables by assets rather than the number of employees.

${ }^{23}$ Core and Guay $(1999,2001)$ argue that current equity holdings also influence the level of new equity grants. We do not include prior holdings in the equity grant prediction models for two reasons. First, since existing holdings are due in large part to prior equity grants and are likely to share the same determinants, including these holdings in the model will tend to reduce the explanatory power of the other predictor variables. Second, the iQuantic survey does not provide data on existing equity holdings by employees at the various hierarchical levels and functions. However, this information is available for the top five executives in the firms' proxy disclosures. To provide some evidence on the relation between existing equity holdings and equity grants, we reestimated the models in Table 5 after including the value of equity holdings and in-the-money options as additional predictor variables. Contrary to Core and Guay's $(1999,2001)$ hypothesis, the value of existing CEO and vice president option holdings is not statistically related to equity grants. Existing equity holdings are also insignificant in the vice president model, and are positively associated with CEO option grants, opposite Core and Guay's $(1999,2001)$ prediction. The significance of the remaining variables changes little. Prior ROA and the eastern region indicator are now significant and positive in the CEO model, while cash level is no longer significant in the vice president model.
} 


\subsection{Comparison of Executive Equity Grant Determinants in Old and New Economy Firms}

The results in Table 5 indicate that at least some of the hypothesized economic determinants are associated with equity grants to executives of new economy firms. However, the tests provide no direct evidence on the extent to which these determinants are similar to or different than those for old economy firms. We examine this issue by estimating the equity grant determinants models after pooling our sample of new economy firms and the "old economy" manufacturers discussed in Section 3.5. Since the program objectives variables are not available for the old economy firms, they are excluded from the models. We also exclude other variables that are not relevant to the old economy firms (the two location variables and YR2000 indicator) and the two blockholder measures (Num Blockholders and Block Ownership Pct).

Our first test estimates equity grants to executives as a function of the remaining predictor variables, but allows the intercept to vary across the two samples by including an indicator variable for new economy firms. If the same economic model applies to both new and old economy firms, this test allows us to determine whether equity grants in new economy firms are actually higher than those in their old economy counterparts after controlling for differences in firm characteristics. This approach is similar to that used by Anderson, Banker, and Ravindran (2000) in their study of compensation practices in information technology firms relative to more traditional firms. Our second test allows both the intercept and slope coefficients to vary across the two subsamples by incorporating interactions between the new economy indicator and the predictor variables, as well as the new economy indicator alone. In this manner, we can examine whether the relative importance of the hypothesized equity grant determinants also differs across the two sectors.

The results are provided in Table 6 . When only the intercept is allowed to vary, the new economy indicators are positive and highly significant $(\mathrm{p}<0.001$, two-tailed) in both the CEO and vice president models, indicating that the common equity grant model does not fully explain differences in compensation practices in old and new economy firms. The other results are generally similar to those in the new economy sample. Two exceptions are Leverage in the CEO model, which is no longer 
significant, and Volatility in the vice president model, which is now statistically positive. More importantly, the coefficients on Cash Flow/Employee and Cash Level/Employee are significantly different in the pooled sample. In the earlier new economy tests, these variables were positively related to CEO equity grants, with Cash Level/Employee also positively related to vice president grants. In the pooled sample, the coefficient on Cash Level/Employee is negatively related to CEO grants and the coefficient on Cash Flow/Employee is negatively related to vice president grants. This evidence suggests that the influence of available cash on the form of compensation differs between old and new economy firms.

When we allow the intercept and slopes to vary across sectors, several significant differences emerge between the two groups. The investment opportunity set plays a much more important role in determining equity grants in new economy firms than in the old economy manufacturers. The interaction between the new economy indicator and InvestOppSet is positive and highly significant $(\mathrm{p}<0.001$, twotailed) for CEOs and vice presidents. These results are consistent with Balkin, Markman, and GomezMejia (2000), who find a stronger association between equity-based compensation and an innovation construct in high technology manufacturers than in other manufacturers.

The other significant differences relate to vice president grants. Both Prior Return and Cash Level/Employee have more positive effects on vice president equity grants in new economy firms. Volatility and Low Tax, on the other hand, have significantly smaller coefficients. Consistent with the prior evidence, the positive coefficient on the interaction between the new economy indicator and Cash Level/Employee is larger in absolute value than the negative coefficient on Cash Level/Employee alone, again indicating that the availability of cash for compensation purposes has opposite effects on equity grants in new and old economy firms.

When differences in slope coefficients are taken into account, the new economy intercept term remains significant in both models ( $\mathrm{p}<0.001$, two-tailed). This evidence suggests that new economy firms provide a larger percentage of compensation to vice presidents in the form of equity grants, even after taking the hypothesized economic determinants into account. In sum, the results in Table 6 suggest that the relative importance of some of the factors influencing executive equity granting practices in new 
economy firms is significantly different than those in old economy manufacturers, but that these differences do not completely explain the higher equity grants in this sector.

\subsection{Determinants of Equity Grants to Non-Executives and Across Functional Areas}

Table 7 extends the analysis to examine the determinants of equity grants to non-executives and across the various functional areas. Since compensation data for lower-level employees are not publicly available, our tests are limited to the new economy sample. The adjusted $\mathrm{R}^{2} \mathrm{~s}$ range from 0.203 to 0.284 . Similar to the executive-level results, the most consistent predictors are InvestOppSet, Employees, and Cash Level/Employees, all of which are positively related to non-executive equity grants. The significant positive coefficients on Employees support Core and Guay's (2001) hypothesis that larger firms use nonexecutive equity grants to a greater extent because monitoring costs are higher. However, whereas Core and Guay's (2001) examination of stock option grants to non-executives in a broad cross-section of firms finds a positive association with cash constraints, we again find that new economy firms that are less cash constrained (i.e., have more cash available for compensation purposes) tend to make larger equity grants to non-executives, and no evidence that cash constraints are associated with greater use of equity grants.

External monitoring also appears to play a role in the use of equity grants to lower-level employees. The coefficient on the percentage of equity held by five percent blockholders (Block Ownership Pct) is negative in every model, and significant in the manager, individual contributor, technical, and sales groups. This result is consistent with the earlier vice president results, as well as with Engel, Gordon, and Hayes (2001), who find the use of equity-based incentives for CEOs in new IPOs to be negatively related to the level of venture capitalist involvement in the firm. Leverage is consistently negative and is significant in the director, manager, and technical models, again suggesting that monitoring by bond holders is a substitute for equity-based incentives. The other predictor variables are generally insignificant. In particular, Attraction Objective and Retention Objective are not significant in any of the models, implying that these goals have little effect on the extent to which annual compensation for non-executives is equity-based. 


\subsection{Determinants of Equity Grants for New Hires}

The insignificant associations between attraction and retention requirements and ongoing equity grants provide no evidence that the relative importance of these requirements influences granting behavior, despite survey participants' claims that attraction and retention issues are primary objectives of their equity grant programs. To examine this issue in more detail, we investigate the determinants of equity grants to newly hired employees. These data are the average equity grants actually made to new hires. We expect attraction and retention issues to be relatively more important in this setting for a number of reasons. First, attraction objectives are more closely related to newly hired employees than to existing employees. Second, new hires have no existing equity incentives with features such as vesting periods that are claimed to promote retention, and are likely to have few if any equity holdings in the firm. As a result, new equity grants may be required to provide the retention incentives that would otherwise be provided by existing equity and option holdings. In fact, equity grants to new hires are substantially larger than ongoing grants in our sample. The mean (median) ratio of grants to new hires relative to ongoing grants are $1.82(1.52)$ for vice presidents, $1.70(1.49)$ for directors, $1.54(1.30)$ for managers, 1.64 (1.32) for individual contributors, 1.85 (1.09) for non-exempts, 1.83 (1.46) for technical employees, $1.86(1.41)$ for non-technical employees, and $1.53(1.20)$ for sales personnel. Finally, since the past performance of the firm occurred before the new employees were hired, the initial equity grants should not be confounded by efforts to use equity grants to reward or penalize past employee performance.

The estimation results for new hires are provided in Table 8 . Since only 18 firms reported information for newly hired CEOs, this hierarchical level is not included in the analysis. In contrast to the earlier results, the importance of retention objectives is positively associated with new hire grants, and is statistically significant ( $\mathrm{p}<0.10$, two-tailed) for all levels except non-exempts. Similarly, the investment opportunity set, which is also likely to reflect greater need for employee retention (Core and Guay, 2001), is positive in every model and significant for lower hierarchical levels (managers on down) and in nontechnical and sales functions. Although the coefficients on Attraction Objective are generally positive, 
none is statistically significant. In addition, the coefficients on Employee Growth are all negative and are only significant in the non-exempt model. These results indicate that retention objectives are important determinants of new hire equity grants in these firms, but provide no evidence that attraction objectives influence these grants.

Consistent with our earlier findings, Cash Level/Employee is positively associated with new hire grants below the vice president level, providing no support for claims that new economy firms under cash constraints use equity grants in place of cash compensation. This finding is supported by significant positive coefficients on Cash Flow/Employee in the director, manager, and technical models. Surprisingly, prior stock returns are positively related to grants to managers, individual contributors, and non-exempt employees. One explanation for these results is that following a period of good stock market performance, new hires are optimistic about future performance, and so their demand for options increases. ${ }^{24}$ Another possibility is that existing employees are awarded more options as a reward for past behavior, with new hires also receiving higher than "normal" equity grants to maintain internal equity within the firm's compensation structure. Though plausible, this interpretation is inconsistent with the insignificant relations between the past performance variables and ongoing equity grants found in earlier tests. Finally, new hire grants to non-technical employees are negatively associated with the number of employees, and employee growth is negatively associated with new hire grants to non-exempts. None of the other coefficients is significant at the ten percent level (two-tailed).

\footnotetext{
${ }^{24}$ This interpretation is consistent our finding (in untabulated correlations between the hypothesized determinants of equity grants and the self-reported objectives for using equity grants described in Table 2) that Prior Return has a significant positive association with the use of stock option plans for attracting employees.
} 


\section{Performance Consequences of Equity Grants}

\subsection{Methodological Issues}

In this section, we provide some exploratory analysis of the relation between the equity grant decisions and subsequent accounting and stock price performance. An important issue that limits these tests is the endogenous nature of compensation plan design. As discussed in Demsetz and Lehn (1985), if all organizations in the sample are optimizing with respect to equity grants, there should be no statistical association between organizational performance and the observed endogenous choice, once the exogenous determinants of this choice are controlled in the structural model. Under this scenario, any statistically significant coefficient on the equity grant choice will only occur because of measurement error, misspecification of functional form, inadequate set of exogenous controls, etc. ${ }^{25}$

An alternative to the Demsetz and Lehn (1985) perspective is that new economy firms are dynamically learning and moving toward their optimal equity grant levels, but that our cross-sectional sample consists of observations that are distributed around the sample firms' optimal incentive practices. This perspective is advocated by Milgrom and Roberts (1992, p. 43), who contend that tests of economic theories of the benefits of organizational practices such as equity grants require the very imperfections in the rationality of people and the adaptability of organizations denied by many economic theories.

According to Milgrom and Roberts (1992, p. 43), a more defensible position is that people learn to make good decisions and that organizations adapt by experimentation and imitation. Thus, at any given point in time, a cross-sectional sample will be composed of organizations that vary with respect to the optimal adoption of a given practice. As a result, the observed cross-sectional variation in equity grant practices provides a means for assessing the performance consequences of this organizational choice.

\footnotetext{
${ }^{25}$ Another limitation to this analysis is the difficulty in detecting performance differences over multi-year time periods (see Barber and Lyon $(1996,1997)$ for discussions of the limitations of long-window performance tests). This specification concern limits our ability to draw strong inferences from our performance tests.
} 
Our approach for examining the performance consequences of equity grants is to examine the association between the residuals from the empirical prediction models in Tables 5 and 7 and subsequent firm performance. If the systematic portion of these models represents the appropriate choice for a firm, then any residual deviation (positive or negative) should adversely affect firm performance. This interpretation is consistent with option grant studies by Core and Guay $(1999,2001)$, which assume that their model of option grant behavior (which includes the traditional predictor variables included in our model) reflects the movement to optimal equity incentive levels. A finding of lower performance in firms that deviate from the predicted equity grant model would support the joint hypothesis that, on average, firms in the new economy have reached their equilibrium compensation practices, and that our prediction model represents optimal practice.

Alternatively, the systematic part of the model can be viewed as the average benchmark for equity grants by similar firms in the sample. In this context, the residual measures the extent to which a firm makes equity grants that are higher or lower than firms with similar characteristics. If the majority of new economy firms are still learning whether their equity grant levels are optimal in this uncertain competitive environment, the negative or positive equity grant residuals represent the extent to which these firms have granted equity with lower or higher values than grants by similar firms, regardless of the optimal level of these grants. Under this scenario, the hypothesized performance consequences of these "unexpected" equity grants is uncertain.

\subsection{Performance Measures}

We investigate the performance consequences of new economy equity grants using subsequent accounting and stock price returns. Both of these performance measures offer advantages and disadvantages. Short-term accounting returns are likely to reflect actual changes in operational performance and are not influenced by the speculative bubble in new economy share prices, but exclude the long-term performance implications that equity grants are typically designed to motivate. In addition, recent articles in the business press suggest that the reported accounting earnings of a number of new 
economy firms during the period under study were manipulated to increase reported accounting returns

(e.g., Kahn, 2000). Stock price returns, on the other hand, incorporate the market's expectation of the

long-term performance implications of these equity grants and are more closely tied to the grants'

ultimate objective of increasing shareholder value. However, the collapse of new economy share prices

in April, 2000 suggests that stock prices are noisy indicators of economic performance in these firms.

Given these strengths and weaknesses, consistent findings across the two performance measures are more

likely to reflect actual changes in performance rather than measurement error.

We investigate accounting return on assets $(R O A)$ in the second year following the option grant.

Stock price performance (RETURN) is measured over the 24 month period after the equity grants. ${ }^{26}$ The

1999 survey collected data for grants that typically were made at the end of 1997 or beginning of 1998 .

Thus, for December fiscal year end firms, we measure firm performance using the average continuously

compounded monthly return (including dividends) over the 24 months starting in April 1998. A similar

approach is used for firms included in the 2000 survey and for firms with different fiscal year ends. This

24-month return covers the pre-collapse period for the 1999 respondents and a mix of pre- and post-

collapse periods for the 2000 respondents. ${ }^{27}$

${ }^{26}$ We choose the second year and 24 month periods to capture at least some of the longer-term performance implications of equity grants. We also estimated performance regressions using ROA one year after the grants, and stock price returns over the 12 month and 36 month periods after the grants. Results using first year ROA and 12 month stock returns were very similar to those using second year ROA and 24 month returns. However, none of the models using 36 month stock returns was statistically significant, due in part to very small sample sizes in these tests.

${ }^{27}$ An important issue in the stock return tests is the whether the anticipated effects of the equity grants on performance are already impounded into stock price by the market. If markets are assumed to be efficient, market prices will impound all expected future performance effects (whether due to incentive, attraction, or retention dimensions) at the date the information about equity grants becomes publicly available. If this is the case, and assuming the market processes this information correctly, we should observe no relation between the equity grant residuals and subsequent performance. However, the market does not necessarily know the optimal level of equity grants ex ante. If true, the market should systematically revise its assessment of the optimal level of grants ex post as it learns more about the consequences of the grant decisions. Furthermore, grants to lower-level employees are not disclosed in detail, making it less likely that the market has already impounded this information into price. 


\subsection{Control Variables}

We include a variety of control variables in the cross-sectional analyses. We first incorporate proxies for existing stock and option holdings to account for the effects of other equity-based incentives on performance. These variables control for Core and Guay's $(1999,2001)$ claim that the incentive effects of equity-based compensation are a function of the employee's entire portfolio of equity holdings. Since the iQuantic survey does not include information on employees' existing equity holdings, we are limited to the information in the firms' proxy statements. Consequently, we control for existing equitybased incentives using the value of stock and option holdings of the firm's top five executives in the year prior to the equity grant. The market value of the executives' stock holdings is based on the stock's closing price at year end. The value of option holdings is proxied by the difference between the market value and exercise price for all in-the-money options, as reported in the proxy statement. Since equity and options potentially have different incentive effects due to their different payoff structures, we include separate variables for equity and option holdings. To maintain consistency with the equity grant variables and provide a measure of the incentive intensity of these holdings, we scale these values using a proxy for the executives' wealth that is not tied to these equity-based incentives. ${ }^{28}$

Similar to the equity grant variables, we attempt to control for endogeneity by estimating the values of existing equity and option holdings as a function of the same independent variables used in the earlier prediction models. ${ }^{29}$ The residuals from these estimates (denoted Equity Residual and Options Residual, respectively) represent "unexpected" stock and option holdings. We include separate variables for positive and negative residuals to allow for potential differences between equity and option holdings that are larger or smaller than predicted.

\footnotetext{
${ }^{28}$ We scale existing equity (option) holdings by the value of equity (option) holdings plus ten times the executives' salary. Our results are robust to measuring wealth using five or fifteen times salary.

${ }^{29}$ The adjusted $\mathrm{R}^{2} \mathrm{~s}$ are 0.579 in the equity holding prediction model and 0.379 in the options holding model. InvestOppSet, Employees, Cash Level/Employee, and Prior Return are positive and significant in both models, and Cash Flow/Employee is negative and significant in both models. Attraction Objective, Retention Objective, Employee Growth, and Prior ROA are positively associated with equity holding. Blockholder Pct is negatively associated with equity holdings, while Volatility and High Tax are negatively associated with option holdings.
} 
We also include six industry indicators (computer, software, semiconductor, telecommunications, networking, and internet) and an indicator for the year of data collection (thereby controlling for the collapse in new economy share prices). These indicator variables control for industry-specific and time period-specific variations in performance that are unrelated to the equity grants (e.g., the collapse in new economy share prices). Since, small firms and firms with high book-to-market ratios tend to earn higher rates of return (e.g., Fama and French, 1992), we include past realizations of these two factors as control variables. Given the innovative, technological nature of our sample, we also include InvestOppSet as a control variable, as well as past volatility to control for firm risk. Finally, prior return on assets is included in the ROA model to control for autocorrelation in accounting returns.

\subsection{ROA Results}

The $R O A$ results are reported in Table 9. Adjusted $\mathrm{R}^{2} \mathrm{~s}$ range from 0.142 to 0.485 , with the greatest explanatory power in the $\mathrm{CEO}$ and technical employee models. We find consistent evidence that firms with option grants and holdings that are lower than predicted by the benchmark model have lower accounting performance in subsequent years. Smaller than expected equity grants to CEOs, directors, and technical employees are associated with lower accounting returns at the ten percent level or better (twotailed), while smaller than expected equity grants to non-technical employees are negatively associated with ROA at the twelve percent level (two-tailed). ROA also has a significant positive association with Options Residual in all but one of the models, indicating that lower than expected option holdings by top five executives are associated with lower accounting returns.

In contrast, we find almost no evidence that firms with larger than expected grants or holdings have lower subsequent accounting returns. Only one coefficient on Grant Residual ${ }^{+}$is negative and statistically significant, and then at the fifteen percent level (two-tailed). In addition, all of the coefficients on Options Residual ${ }^{+}$and Equity Residual ${ }^{+}$are positive, with several marginally significant (p $<0.15$, two-tailed). Most surprising are the significant negative coefficients on Equity Residual in the director, technical, and non-technical models. These results indicate that lower than expected equity 
holdings by top five executives are associated with higher ROA. The exploratory results in Table 9 provide some evidence that unexpectedly low option grants to executives and technical employees and unexpectedly small option holdings by executives have a significant, negative association with subsequent accounting returns, but provide limited and mixed evidence that executives' existing equity holdings or higher than expected option levels influence future ROA.

\subsection{Stock Price Returns}

Similar analyses using stock price returns as the performance variable are presented in Table 10. The adjusted $\mathrm{R}^{2} \mathrm{~s}$ range from 0.088 to 0.270 . Equity grants are statistically associated with stock returns in relatively few cases. Instead, any stock market performance effects of equity-based incentives appear to be related to total equity and option holdings by executives. Options Residual ${ }^{-}$is positive and significant in all but one model. This result is similar to the significant positive coefficients on Options Residual in the ROA models, and again suggests that lower than expected option holdings by top five executives are associated with lower subsequent performance. Also consistent with the ROA results are the significant negative coefficients on Equity Residuat in most regressions in Table 10. This unexpected result implies that stock returns are higher when top executives' equity holdings are lower than expected. The results for positive deviations from the benchmark models are mixed. Neither Options Residual ${ }^{+}$nor Equity Residual ${ }^{+}$is statistically insignificant in any of the models. Combined with the ROA results, the stock return evidence suggests that lower than expected executive option holdings have a significant, negative relation with future performance. In contrast, lower than expected equity holdings are associated with higher performance, an unexpected finding requiring additional research.

\section{Summary and Conclusions}

This paper examines the structure and performance consequences of equity grants to employees of new economy firms. We find that the relative importance of a number of factors influencing executive equity granting practices in new economy firms are substantially different than those in old economy manufacturers. We then examine the economic determinants of annual equity grants across lower levels 
of the organizational hierarchy and across different functional areas of new economy firms. We find that employee retention objectives, which new economy firms rank as the most important goal of their equity grant programs, have a significant impact on new hire grants, but not on annual, ongoing grants. We next examine whether differences in the structure of equity grants are related to subsequent accounting and stock market performance of new economy firms. Our exploratory performance tests indicate that lower than expected option grants to CEOs, directors, and technical employees are associated with lower accounting performance in subsequent years. Lower than expected existing option holding by top executives are also associated with lower stock returns. However, greater than expected equity grants have relatively little association with future performance, providing no support for claims that the large equity grants by new economy firms have a substantial negative impact on shareholder value.

Furthermore, lower than expected equity holding by top five executives have an unexpected negative association with both return on assets and stock returns, providing preliminary evidence that future performance is higher when equity holdings are lower than expected. Finally, the accounting and stock return tests provide little evidence that equity grants to broad groups of lower-level employees (managers down to non-exempt workers) are associated with performance differences.

Our results are subject to a number of important limitations. First, due to data limitations we do not have existing equity and option holdings for non-executives. Second, although we have attempted to include all relevant economic determinants in our benchmark models, the statistical results suggest that other factors affect the choice of equity grants in the new economy. Similarly, the large unexplained variance in the performance tests indicates that our predictor variables capture only a fraction of the determinants of accounting and stock price returns. Third, our performance analyses must be viewed as exploratory given prior research on the difficulties assessing the long-term performance implications of endogenous organizational choices. Fourth, there is always the possibility of self-selection in survey responses, which limits our ability to generalize the results. Finally, our interpretations are limited by potential measurement error in our choice of indicators for the predictor constructs, particularly our marginal tax constructs. Despite these limitations, our study provides some of the first evidence on the 
determinants of equity grants to both upper-level and lower-level executives, as well as exploratory insights into the performance benefits from equity grants to employees in different functions and hierarchical levels. 


\section{References}

Aboody, D., 1996. Market valuation of employee stock options, Journal of Accounting and Economics $22,357-391$.

Abowd, J., 1990. Does performance-based managerial compensation affect corporate performance? Industrial and Labor Relations Review 43, 52-S - 73-S.

Anderson, M., Banker, R., Ravindran, S., 2000. Executive compensation in the information technology industry. Management Science 46, 530-547.

Baber, W., Janakiraman, S., Kang, S., 1996. Investment opportunities and the structure of executive compensation. Journal of Accounting and Economics 21, 297-318.

Baker, G., 1992. Incentive contracts and performance measurement. Journal of Political Economy 100, 598-614.

Balkin, D., Markman, G., Gomez-Mejia, L., 2000. Is CEO pay in high technology firms related to innovation?. Academy of Management Journal 23, 1118-1129.

Banker, R., Datar, S., 1989. Sensitivity, precision, and linear aggregation of signals for performance evaluation. Journal of Accounting Research 27, 21-39.

Barber, B., Lyon, J. 1996. Detecting abnormal operating performance: the empirical power and specification of test statistics. Journal of Financial Economics 41, 359-399.

Barber, B., Lyon, J.. 1997. Detecting long-run stock returns: the empirical power and specification of test statistics. Journal of Financial Economics 43, 341-372.

Battey, J., 2000. The keys to recruiting success. Infoworld 22, 73-76.

Bell, T., Landsman, W., Miller, B., Yeh, S., 2000. The valuation implications of employee stock option accounting for computer software firms. Unpublished Working Paper, KPMG LLP, University of North Carolina at Chapel Hill, and University of California at Los Angeles.

Blasi, J., Conte, M., Kruse, D., 1996. Employee stock ownership and corporate performance among public companies. Industrial \& Labor Relations Review 50, 60-79.

Brandel, M., 2000. Rising in riches. Computerworld 34, 48-53.

Clinch, G., 1991. Employee compensation and firms' research and development activity. Journal of Accounting Research 29, 59-78.

Conyon, M., Freeman, R., 2000. Shared modes of compensation and firm performance: UK evidence, Unpublished Working Paper, University of Pennsylvania and London School of Economics.

Core, J., Guay, W., 1999. The use of equity grants to manage optimal equity incentive levels. Journal of Accounting and Economics 28, 151-184.

Core, J., Guay, W., 2001. Stock option plans for non-executive employees. Journal of Financial Economics 61, 253-287. 
Core, J., Qian, J., 2000. Option-like contracts for project selection and production. Unpublished Working Paper, University of Pennsylvania.

Coy, P., 1999. The drawbacks of stock-option fever. Business Week 3659: 204.

DeFusco, R., Johnson, R., Zorn, T., 1990. The effect of executive stock option plans on stockholders and bondholders. Journal of Finance 45, 617-627.

Demsetz, H., Lehn, K. 1985. The structure of corporate ownership: causes and consequences. Journal of Political Economy 93, 1155-1171.

Engel, E., Gordon, E., Hayes, R., 2001. Incentives and governance in entrepreneurial firms. Unpublished Working Paper, University of Chicago.

Fama, G., French, K., 1992. The cross-section of expected returns. Journal of Finance 47, 427-465.

Gaver, J., Gaver, K., 1993. Additional evidence on the association between the investment opportunity set and corporate financing, dividend, and compensation policies. Journal of Accounting and economics 16, $125-160$.

Graham, J., 2000. How big are the tax benefits of debt?. Journal of Finance 55, 1901-1941.

Grice, J. and Harris, R., 1998. A comparison of regression and loading weights for the computation of factor scores. Multivariate Behavioral Research 33, 221-247.

Kahn, J., 2000. Presto chango! Sales are huge!. Fortune 141, 90-96.

Hanlon, M., Shevlin, T. 2001. Accounting for tax benefits of employee stock options and implications for research. Unpublished Working Paper, University of Washington.

Hagerty, K., Siegel, D., 1988. On the observational equivalence of managerial contracts under conditions of moral hazard and self-selection. The Quarterly Journal of Economics 103, 425-428.

Hemmer, T., Kim, O., Verrecchia, R., 2000. Introducing contract convexity into optimal compensation contracts. Journal of Accounting and Economics 28, 307-327.

Holmstrom, B., 1979. Moral hazard and observability. Bell Journal of Economics 10, 74-91.

Holthausen, R., Larcker, D., Sloan, R., 1995. Business unit innovation and the structure of executive compensation. Journal of Accounting and Economics 19, 279-313.

Innes, R., 1990. Limited liability and incentive contracting with ex-ante action choices. Journal of Economic Theory 52, 45-67.

iQuantic, Inc., 1999. Executive Total Direct Compensation Survey for the High Technology Industries. iQuantic, Inc., San Francisco, CA.

Janakiraman, S., 1998. Option awards and option exercise behavior of CEOs: an empirical analysis. Unpublished Working Paper, University of Texas at Dallas. 
Keating, E., Lys, T., Magee, R., 2001. The internet downturn: finding valuation factors in spring 2000. Unpublished Working Paper, Northwestern University.

Lambert, R., 1986. Executive effort and the selection of risky projects. Rand Journal of Economics 17, $77-88$.

Lambert, R., Larcker, D., Verrecchia, R., 1991. Portfolio considerations in valuing executive compensation. Journal of Accounting Research 29, 129-149.

Lambert, R., Larcker, D., Weigelt, K., 1993. The structure of organizational incentives. Administrative Science Quarterly 38, 438-451.

Lewellen, W., Loderer, C., Martin, K., 1987. Executive compensation and executive incentive problems: an empirical analysis. Journal of Accounting and Economics 9, 287-310.

Milgrom, P., Roberts, J., 1992. Economics, Organization \& Management. Prentice Hall, Englewood Cliffs, NJ,

Pepe, M., 1998. Key to success: sharing the wealth with employees. Computer Reseller News 794, 169.

Plesko, G., 1999. An evaluation of alternative measures of corporate tax rates. Unpublished Working Paper, Massachusetts Institute of Technology.

Portnot, S., Moltzen, E., 2000. High-tech execs chase the dot-com dream. Computer Reseller News 895, 80.

Prendergast, C., 2000. What trade-off of risk and incentives?. American Economic Review 90, 421-425.

Rajgopal, S., Shevlin, T., 2000. Stock option compensation and risk taking: the case of oil and gas producers. Unpublished Working Paper, University of Washington.

Sesil, J., Kroumova, M., Blasi, J., Kruse, D., 2000. Broad-based employee stock options in "new economy" firms: company performance effects. Unpublished Working Paper, Rutgers University.

Sesil, J., Kroumova, M., Kruse, D., Blasi, J., 2000. Broad-based employee stock options in the U.S: company performance and characteristics. Unpublished Working Paper, Rutgers University.

Smith, C., Watts, R., 1992. The investment opportunity set and corporate financing, dividend, and compensation policies. Journal of Financial Economics 32, 263-292.

Welles, E., 1998. Motherhood, apple pie \& stock options. Inc. 20, 84-97.

Yermack, D., 1995. Do corporations award CEO stock options effectively?. Journal of Financial Economics 39, 237-269. 


\section{Appendix A}

\section{Variable Definitions}

$\%$ EQUITY GRANT $=$ (the value of stock option and restricted stock grant)/(the value of stock option and restricted stock grant + employee salary). Stock options are valued using the discounted expected gain approach, with an assumed annual stock price growth of $15 \%$, a five year holding period before the option is exercised, and a risk-free rate of 5\%. Restricted stock is valued by multiplying the number of shares by the fair market value of a share at the date of grant

$B o o k / M a r k e t=$ ratio of book value to market value of equity in year prior to equity grant

$R \& D /$ Sales $=$ ratio of research and development expenditures to annual sales in the year prior to equity grant

$A d v /$ Sales $=$ ratio of advertising expenditures to annual sales in the year prior to equity grant.

Sales Growth $=$ growth in annual sales in the year prior to equity grant.

Volatility $=$ standard deviation of continuous compounded monthly returns during the year prior to equity grant.

Prior Return = average continuously compounded monthly return during the year prior to equity grant.

Prior $R O A=$ ratio of earnings before taxes to total assets in the year prior to equity grant.

Employees $=$ natural $\log$ of the number of employees in thousands in the year prior to equity grant.

Leverage $=$ ratio of long-term debt to total assets in the year prior to equity grant.

High Tax = indicator variable equal to one if a firm has a positive pretax book income and no net operating loss carry-forwards, and zero otherwise in the year prior to equity grant.

Low Tax = indicator variable equal to one if a firm has a negative pretax book income and net operating loss carry-forwards, and zero otherwise in the year prior to equity grant.

Cash Flow/Employee = net cash flow from operating activities minus cash dividends, capital expenditures, and research and development expenditures divided by the number of employees in the year prior to equity grant.

Cash Level/Employee $=$ the book value of cash plus the book value of marketable securities minus the book value of current liabilities.

Employee Growth = growth in number of employees in the year prior to equity grant.

West Location $=$ indicator variable equal to one if the firm is headquartered in the Western region, and zero otherwise. 
East Location = indicator variable equal to one if the firm is headquartered in the Eastern region, and zero otherwise.

Attraction Objective $=$ relative ranked importance of attracting new employees $($ minimum $=0$; maximum $=100)$.

Retention Objective $=$ relative ranked importance of retaining new employees $($ minimum $=0 ;$ maximum $=$ $100)$.

$Y R 2000=$ indicator variable equal to one if the survey was conducted during calendar year 2000, and zero otherwise.

Num Blockholder $=$ number of five percent blockholders in the year prior to equity grant.

Blockholder Pct $=$ proportion of outstanding shares held by blockholders in the year prior to equity grant

InvestOppSet $=$ average of the standardized scores for Book/Market, R\&D/Sales, Adv/Sales, Sales Growth, and natural logarithm of company age (years since IPO). Book/Market and natural logarithm of company age are reverse coded.

Market Value $=$ market value of equity in the year prior to the equity grant. 


\section{Table 1}

Descriptive Statistics for the Sample $(n=217)$

\begin{tabular}{lcc}
\hline A. Primary Location & $\begin{array}{c}\text { Number of } \\
\text { Firms }\end{array}$ & \% of Sample \\
\hline East & 41 & $18.9 \%$ \\
Midwest & 9 & $4.1 \%$ \\
South & 16 & $7.4 \%$ \\
West & 148 & $68.2 \%$ \\
Canada & 3 & $1.4 \%$ \\
\hline
\end{tabular}

\begin{tabular}{lcc}
\hline B. Industry & $\begin{array}{c}\text { Number of } \\
\text { Firms }\end{array}$ & \% of Sample \\
\hline Computers/Computer Peripherals & 25 & $11.5 \%$ \\
Software/Software Services & 56 & $25.8 \%$ \\
Semiconductors/Semiconductor Manufacturing & 42 & $19.4 \%$ \\
Telecommunications & 27 & $12.4 \%$ \\
Networking & 16 & $7.4 \%$ \\
Internet/E-Commerce & 29 & $13.4 \%$ \\
Other $^{\mathbf{a}}$ & 22 & $10.1 \%$ \\
\hline
\end{tabular}

\begin{tabular}{lcc}
\hline C. Year of IPO & $\begin{array}{c}\text { Number of } \\
\text { Firms }\end{array}$ & \% of Sample \\
\hline Before 1990 & 70 & $32.3 \%$ \\
1990 & 7 & $3.2 \%$ \\
1991 & 6 & $2.8 \%$ \\
1992 & 6 & $2.8 \%$ \\
1993 & 17 & $7.8 \%$ \\
1994 & 11 & $5.1 \%$ \\
1995 & 11 & $5.1 \%$ \\
1996 & 20 & $9.2 \%$ \\
1997 & 13 & $6.0 \%$ \\
1998 & 12 & $5.5 \%$ \\
\hline
\end{tabular}

${ }^{\mathrm{a}}$ The industries represented in this segment include medical instruments, instruments, and miscellaneous. 


\section{Table 2}

\section{Relative Importance of Self-Reported Objectives for Stock Option and Restricted Stock Programs}

\begin{tabular}{lcc}
\hline \multicolumn{1}{c}{ A. Objective of Stock Option Program $(\mathbf{n}=\mathbf{1 9 4})$} & Mean $^{\mathbf{a}}$ & $\begin{array}{c}\text { Standard } \\
\text { Deviation }\end{array}$ \\
\hline Retain & 89.7 & 19.2 \\
Reward Specific Project Milestones or Goals & 68.5 & 25.7 \\
Attract & 65.1 & 23.7 \\
Encourage Stock Ownership & 51.4 & 30.7 \\
Reward Past Contributions & 38.4 & 29.5 \\
Provide Competitive Total Compensation & 30.7 & 25.4 \\
Other & 2.4 & 14.1 \\
\hline
\end{tabular}

\begin{tabular}{lcc}
\hline B. Objective of Restricted Stock Program $(\mathbf{n}=\mathbf{5 3})$ & Mean $^{\mathbf{a}}$ & $\begin{array}{c}\text { Standard } \\
\text { Deviation }\end{array}$ \\
\hline & & \\
Retain & 71.5 & 38.7 \\
Attract & 44.1 & 43.9 \\
Link Individual to Company Performance & 44.0 & 40.2 \\
Provide Competitive Total Compensation & 42.8 & 36.7 \\
Reward Performance & 33.5 & 34.2 \\
Encourage Stock Ownership & 23.2 & 27.7 \\
Reward Specific Project Milestones or Goals & 13.9 & 26.8 \\
Minimize Dilution & 8.8 & 16.1 \\
Other & 5.8 & 20.8 \\
\hline
\end{tabular}

${ }^{a}$ Respondents were asked to rank these objectives, with ties allowed. The ranks for each company were then rescaled to range from 0 (not ranked) to 100 (highest rank). A mean value of 100 means that every respondent rated this objective as the most important objective for their stock option or restricted stock program. 
Table 3

Descriptive Statistics for the Annual Salary and Equity Grants Across Hierarchical Levels and Function Areas

\begin{tabular}{|c|c|c|c|c|c|c|}
\hline \multirow[b]{2}{*}{$\begin{array}{l}\text { Hierarchical Level or } \\
\text { Functional Area }\end{array}$} & \multicolumn{2}{|c|}{ Salary } & \multicolumn{2}{|c|}{$\begin{array}{c}\text { Value of } \\
\text { Equity Grant }\end{array}$} & \multicolumn{2}{|c|}{$\begin{array}{c}\text { Ratio of Equity Grant } \\
\text { to Equity Grant }+ \\
\text { Salary } \\
\end{array}$} \\
\hline & Mean & Median & Mean & Median & Mean & Median \\
\hline Chief Executive Officer $(n=112)$ & $\$ 429,353$ & $\$ 500,000$ & $\$ 5,203,42$ & $\$ 2,582,500$ & 0.7820 & 0.8691 \\
\hline Vice President $(\mathrm{n}=182)$ & $\$ 228,407$ & $\$ 223,958$ & $\$ 864,344$ & $\$ 513,960$ & 0.6926 & 0.7291 \\
\hline Director $(n=167)$ & $\$ 144,334$ & $\$ 143,750$ & $\$ 159,226$ & $\$ 99,535$ & 0.4715 & 0.4671 \\
\hline Manager $(\mathrm{n}=133)$ & $\$ 115,154$ & $\$ 113,095$ & $\$ 73,755$ & $\$ 43,510$ & 0.3457 & 0.3059 \\
\hline Individual Contributor $(\mathrm{n}=166)$ & $\$ 88,243$ & $\$ 87,500$ & $\$ 44,135$ & $\$ 26,497$ & 0.2992 & 0.2579 \\
\hline Non-Exempt $(\mathrm{n}=165)$ & $\$ 46,220$ & $\$ 40,000$ & $\$ 5,692$ & $\$ 1,922$ & 0.1241 & 0.1080 \\
\hline Technical $(\mathrm{n}=179)$ & $\$ 112,616$ & $\$ 112,500$ & $\$ 96,664$ & $\$ 63,634$ & 0.4214 & 0.3945 \\
\hline Non-Technical $(\mathrm{n}=169)$ & $\$ 107,458$ & $\$ 108,333$ & $\$ 83,737$ & $\$ 52,661$ & 0.4018 & 0.3807 \\
\hline Sales $(n=128)$ & $\$ 124,294$ & $\$ 118,750$ & $\$ 66,607$ & $\$ 36,048$ & 0.3073 & 0.2672 \\
\hline
\end{tabular}

Salary is the average salary compensation for this hierarchical level or functional area. The value stock option grant is the average number of stock options and restricted stock granted for this hierarchical level or functional area. Stock options are valued using the discounted expected gain approach, with an assumed annual stock price growth of $15 \%$, a five year holding period before the option is exercised, and a risk-free rate of $5 \%$. Restricted stock is valued by multiplying the number of shares by the fair market value of a share at the date of grant 
Table 4

Descriptive Statistics on Equity Grants and Firm Characteristics in New Versus Old Economy Firms

\begin{tabular}{|c|c|c|c|c|c|c|}
\hline & \multicolumn{3}{|c|}{ New Economy Firms } & \multicolumn{3}{|c|}{ Old Economy Firms } \\
\hline & Median & Mean & Std. Dev. & Median & Mean & Std. Dev. \\
\hline \multicolumn{7}{|l|}{ A. Option Grant Characteristics } \\
\hline CEO Equity Grant Percentage & 0.8691 & 0.7820 & 0.2314 & $0.1933 * * *$ & 0.2693 **** & 0.2536 \\
\hline VP Equity Grant Percentage & 0.7291 & 0.6926 & 0.1994 & $0.1326^{* * * * *}$ & 0.1963 **** & 0.2097 \\
\hline \multicolumn{7}{|l|}{ B. Firm Characteristics } \\
\hline Book to Market Value Ratio & 0.2360 & 0.3010 & 0.2218 & 0.3427 **** & 0.3820 米冰 & 0.2271 \\
\hline R\&D to Sales & 0.1328 & 0.2189 & 0.3293 & $0.0093 * * *$ & 0.0523 **** & 0.1453 \\
\hline Advertising to Sales & 0.0000 & 0.0145 & 0.0474 & 0.0000 & 0.0101 & 0.0274 \\
\hline Annual Sales Growth & 0.2158 & 0.8519 & 2.0208 & $0.0796^{* * * *}$ & 0.1463 **** & 0.2928 \\
\hline Market Value of Equity (billions) & 1.1374 & 6.9943 & 18.064 .8 & 1.0340 & $4.4999 * *$ & 9.6952 \\
\hline Std. Dev. of Prior Stock Return & 0.1613 & 0.1744 & 0.0622 & 0.0845 **** & $0.0959 * * *$ & 0.0404 \\
\hline Prior Stock Return & 0.0181 & 0.0176 & 0.0505 & 0.0172 & 0.0161 & 0.0262 \\
\hline Prior ROA & 0.0560 & -0.0557 & 0.3149 & 0.0955 **** & $0.0836 * * *$ & 0.1178 \\
\hline Employees (thousands) & 1.1300 & 10.1100 & 25.7000 & $5.0000 * * *$ & 12.4900 & 18.6500 \\
\hline Long-Term Debt/ Total Assets & 0.0315 & 0.1013 & 0.1600 & $0.1808 * * *$ & $0.1971 * * * *$ & 0.1527 \\
\hline High Tax Rate Indicator & 0.0000 & 0.4648 & 0.4999 & $1.0000 * * *$ & $0.6636^{* * * *}$ & 0.4728 \\
\hline Low Tax Rate Indicator & 0.0000 & 0.1315 & 0.3387 & $0.0000 * * *$ & 0.0518 **** & 0.2217 \\
\hline Available Cash Flow per Employee & -27.1521 & -32.4048 & 53.7910 & $-0.7638 * * *$ & $-20.5360 * * *$ & 73.2494 \\
\hline Available Cash Level per Employee & 12.9080 & 43.4352 & 83.9954 & $-27.2162 * * *$ & $-25.6412^{* * * *}$ & 99.8081 \\
\hline Annual Employee Growth & 0.1608 & 0.2768 & 0.4869 & $0.0512 * * *$ & $0.1079 * * *$ & 0.2422 \\
\hline
\end{tabular}

****** Statistically significant differences between the new and old economy firms at the 5 and 1 percent levels (two-tailed), respectively.

See Appendix A for variable definitions. 


\section{Table 5}

\section{Determinants of Annual Executive Equity Grants in New Economy Firms}

Regression Model: \%EQUITY GRANT G $_{t}=\beta_{0}+\beta_{1}$ InvestOppSet $_{t-1}+\beta_{2}$ Volatility $_{t-1}+\beta_{3}$ Prior Return $_{t-1}+\beta_{4}$ Prior ROA $A_{t-1}+\beta_{5}$ Employees $_{t-1}+\beta_{6}$ Num Blockholders $_{t-1}+\beta_{7}$ Blockholder Pct $_{t-1}+\beta_{8}$ Leverage $_{t-1}+\beta_{9}$ High $_{t}$ $\operatorname{Tax}_{t-1}+\beta_{10}$ Low Tax Tat $_{11}+\beta_{11}$ Cash Flow/Employee El-1 $_{12}+\beta_{12}$ Cash Level/Employee $_{t-1}+\beta_{13}$ Employee Growth $_{t-1}$ $+\beta_{14}$ West Location $+\beta_{15}$ East Location $+\beta_{16}$ Attraction Objective $+\beta_{17}$ Retention Objective $+\beta_{18}$ Year 2000 survey indicator $+\varepsilon_{t \cdot t}$

\begin{tabular}{|c|c|c|c|}
\hline & $\begin{array}{c}\text { Expected } \\
\text { Sign }\end{array}$ & CEO & $\begin{array}{c}\text { Vice } \\
\text { President }\end{array}$ \\
\hline Intercept & & 0.797 **** & 0.666 *** \\
\hline InvestOppSet & + & $0.075 * * *$ & $0.039 * * *$ \\
\hline Volatility & $+/-$ & -0.156 & -0.160 \\
\hline Prior Return & + & 0.135 & 0.110 \\
\hline Prior ROA & + & -0.143 & $0.219 \#$ \\
\hline Num Blockholders & $+/-$ & -0.005 & $0.044 * *$ \\
\hline Block Ownership Pct & - & -0.114 & $-0.510 * *$ \\
\hline Employees & $+/-$ & $0.047 * * *$ & $0.043 * * *$ \\
\hline Leverage & - & $-0.356 * * *$ & -0.140 \\
\hline High Tax & - & $-0.079 * *$ & -0.024 \\
\hline T.ow Tax & + & 0.027 & -0.084 \\
\hline Cash Flow/Employee & - & $0.0009 * *$ & -0.0001 \\
\hline Cash Level/Employee & - & $0.0007^{* * * *}$ & $0.0003^{* *}$ \\
\hline Employee Growth & + & $-0.175 * * *$ & 0.051 \\
\hline West Location & $+/-$ & -0.032 & -0.061 \\
\hline East Location & $+/-$ & 0.115 & -0.020 \\
\hline Attraction Objective & + & -0.0007 & 0.0002 \\
\hline Retention Objective & + & 0.003 *** & 0.0005 \\
\hline YR2000 & & 0.032 & $0.068 * *$ \\
\hline $\mathrm{N}$ & & 73 & 104 \\
\hline Adjusted $\mathrm{R}^{2}$ & & 0.557 & 0.375 \\
\hline F-Statistic & & 6.027 & 4.431 \\
\hline p-value & & 0.000 & 0.000 \\
\hline
\end{tabular}

$\#, *, * *, * * *$ Statistically significant at the $0.15,0.10,0.05,0.01$ levels (two-tailed), respectively.

Note: See Appendix A for variable definitions. 


\section{Table 6}

\section{Comparison of Determinants of Annual Equity Grants At Top Executive Levels in New Versus Old Economy Firms}

Regression Model: $\%$ EQUITY GRANT $T_{t}=\beta_{0}+\beta_{l}$ InvestOppSet $_{t-1}+\beta_{2}$ Volatility $_{t-1}+\beta_{3}$ Prior Return $_{t-1}+$ $\beta_{4}$ Prior ROA $_{t-1}+\beta_{5}$ Employees $_{t-1}+\beta_{6}$ Leverage $_{t-1}+\beta_{7}$ High Tax $_{t-1}+$ $\beta_{10}$ Low Tax Tal $_{1}+\beta_{11}$ Cash Flow/Employee $_{t-1}+\beta_{12}$ Cash Level/Employee $_{t-1}+\beta_{13}$ Employee Growth $_{t-1}+$ NewEconomy Indicators and Interaction Terms $+\varepsilon_{t}$

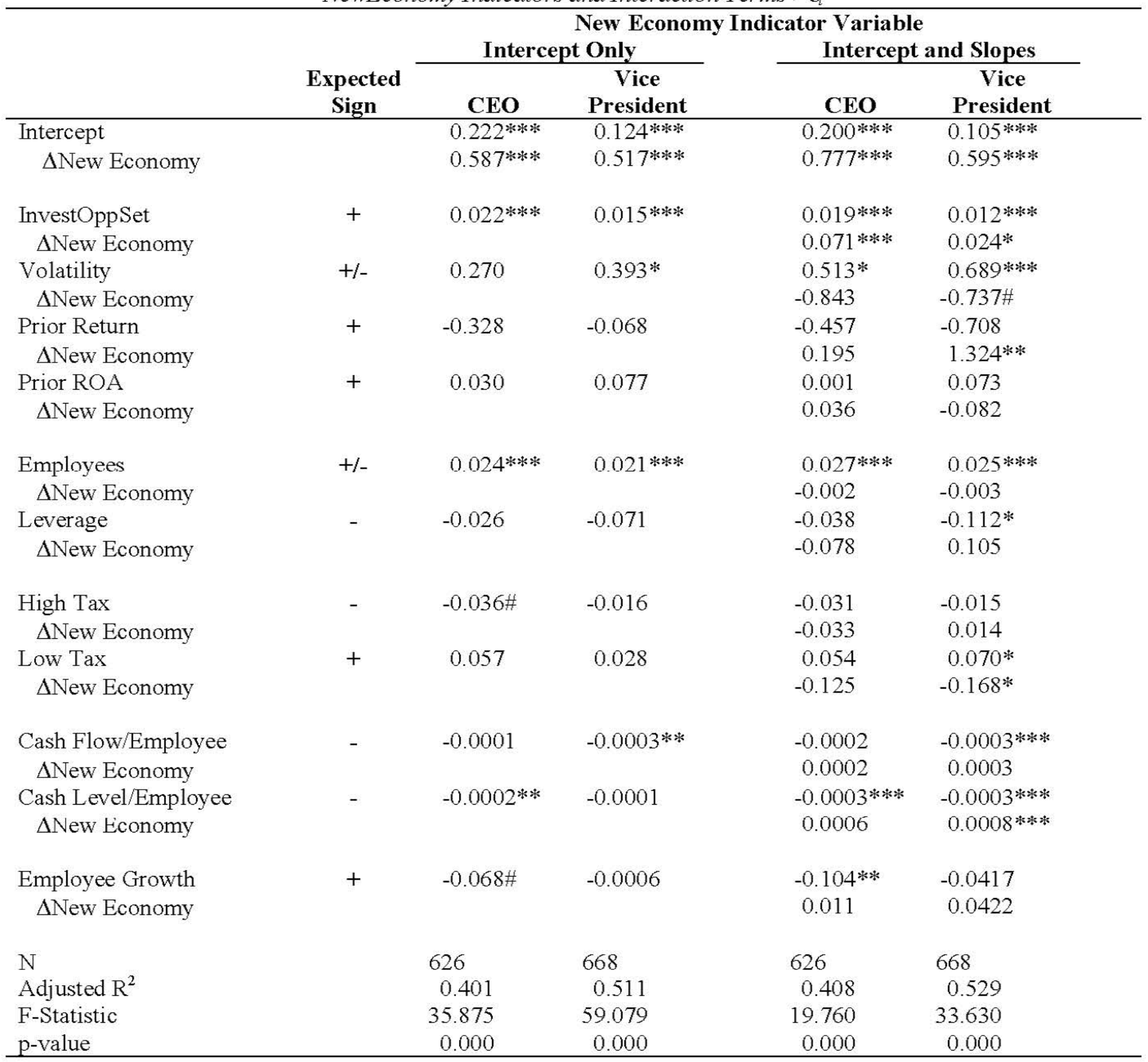

$\#, * * *, * * *$ Statistically significant at the $0.15,0.10,0.05,0.01$ levels (two-tailed), respectively. See Appendix A for variable definitions. 
Table 7

Determinants of Annual Equity Grants Across Non-Executive Hierarchical Levels and Functional Areas

\begin{tabular}{|c|c|c|c|c|c|c|c|c|}
\hline & $\begin{array}{l}\text { Expected } \\
\text { Sign }\end{array}$ & Director & Manager & $\begin{array}{c}\text { Individual } \\
\text { Contributor }\end{array}$ & $\begin{array}{c}\text { Non- } \\
\text { Exempt }\end{array}$ & Technical & $\begin{array}{c}\text { Non- } \\
\text { Technical }\end{array}$ & Sales \\
\hline Intercept & & $0.431^{* * * *}$ & $0.350^{* *}$ & $0.226^{*}$ & 0.083 & $0.436^{* * * *}$ & $0.355^{* * * *}$ & $0.381^{* *}$ \\
\hline InvestOppSet & + & $0.038^{* * *}$ & $0.038^{* * *}$ & $0.026^{* *}$ & $0.021^{* * * *}$ & $0.040^{* * *}$ & $0.033^{* * * *}$ & $0.029 * *$ \\
\hline Volatility & $+/-$ & -0.135 & 0.231 & 0.122 & 0.194 & 0.068 & 0.084 & 0.007 \\
\hline Prior Return & + & 0.322 & 0.376 & $0.513 \#$ & -0.199 & 0.351 & $0.630 \#$ & 0.212 \\
\hline Prior ROA & + & -0.084 & 0.034 & -0.172 & $-0.208^{*}$ & 0.004 & -0.125 & -0.084 \\
\hline Num Blockholders & $+/-$ & 0.028 & 0.029 & 0.025 & -0.004 & $0.038^{*}$ & 0.022 & 0.032 \\
\hline Blockholder Pct & - & -0.387 & $-0.478^{*}$ & $-0.423^{*}$ & -0.071 & $-0.595^{* *}$ & -0.381 & $-0.422 \#$ \\
\hline Employees & $+/-$ & $0.040^{* * * *}$ & $0.040^{* *}$ & $0.035^{* *}$ & 0.011 & $0.033 * *$ & $0.039 * * *$ & $0.040^{* *}$ \\
\hline Leverage & - & $-0.238^{*}$ & $-0.264^{*}$ & -0.065 & -0.060 & $-0.279 * *$ & -0.120 & -0.162 \\
\hline High Tax & - & 0.011 & -0.051 & 0.007 & -0.003 & -0.021 & 0.017 & -0.023 \\
\hline Low Tax & + & -0.074 & $-0.129 \#$ & -0.093 & $-0.065 \#$ & -0.096 & -0.089 & $-0.138 \#$ \\
\hline Cash Flow'Employee & - & 0.0003 & 0.0005 & $0.0007^{*}$ & $0.0004^{*}$ & 0.0002 & 0.0005 & $0.0008^{*}$ \\
\hline Cash Level/Employee & - & $0.0006^{* * *}$ & $0.0006^{* *}$ & $0.0006^{* * * *}$ & $0.0003^{* * *}$ & $0.0006^{* * * *}$ & $0.0006^{* * * *}$ & $0.0006^{* *}$ \\
\hline Employee Growth & + & -0.028 & -0.091 & -0.040 & 0.027 & -0.051 & 0.047 & -0.059 \\
\hline West Location & $+/-$ & 0.016 & 0.004 & $0.114^{* *}$ & 0.008 & -0.001 & 0.046 & 0.017 \\
\hline East Location & $+/-$ & -0.014 & 0.021 & $0.082 \#$ & -0.006 & -0.005 & 0.001 & 0.021 \\
\hline Attraction Objective & + & -0.0003 & -0.0007 & -0.0003 & -0.0002 & -0.0006 & -0.0004 & -0.0005 \\
\hline Retention Objective & + & 0.0007 & 0.006 & -0.0001 & 0.0002 & 0.0005 & 0.0001 & -0.0004 \\
\hline YR2000 & & 0.024 & 0.062 & 0.005 & -0.013 & 0.022 & 0.039 & $0.077^{*}$ \\
\hline $\mathrm{N}$ & & 97 & 83 & 100 & 95 & 101 & 97 & 81 \\
\hline Adjusted $\mathrm{R}^{2}$ & & 0.236 & 0.270 & 0.253 & 0.284 & 0.259 & 0.270 & 0.203 \\
\hline F-Statistic & & 2.647 & 2.689 & 2.861 & 3.073 & 2.397 & 2.976 & 2.130 \\
\hline p-value & & 0.002 & 0.002 & 0.001 & 0.000 & 0.000 & 0.000 & 0.015 \\
\hline
\end{tabular}

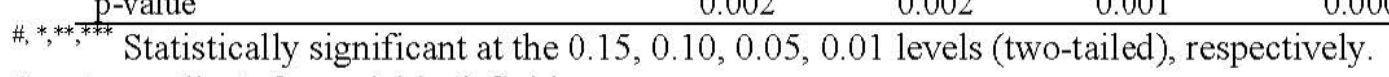

See Appendix A for variable definitions. 
Table 8

Determinants of New Hire Equity Grants Across Hierarchical Levels and Functional Areas

\begin{tabular}{|c|c|c|c|c|c|c|c|c|c|}
\hline & $\begin{array}{l}\text { Expected } \\
\text { Sign } \\
\end{array}$ & $\begin{array}{c}\text { Vice } \\
\text { President } \\
\end{array}$ & Director & Manager & $\begin{array}{c}\text { Individual } \\
\text { Contributor }\end{array}$ & $\begin{array}{c}\text { Non- } \\
\text { Exempt }\end{array}$ & Technical & $\begin{array}{c}\text { Non- } \\
\text { Technical } \\
\end{array}$ & Sales \\
\hline Intercept & & 0.217 & 0.225 & 0.162 & 0.134 & 0.019 & 0.218 & $0.355^{* * * *}$ & 0.110 \\
\hline InvestOppSet & $+^{a}$ & 0.012 & 0.018 & $0.036^{* *}$ & $0.041^{* *}$ & $0.019 \#$ & 0.019 & $0.033 * * *$ & $0.043^{* *}$ \\
\hline Volatility & $+/-$ & 0.858 & 0.200 & 0.143 & 0.085 & $0.584 \#$ & 0.131 & 0.084 & -0.055 \\
\hline Prior Return & + & 0.167 & 0.659 & $0.931^{*}$ & $0.905^{*}$ & $1.380^{* * * *}$ & 0.519 & $0.630 \#$ & $0.903 \#$ \\
\hline Prior ROA & + & -0.086 & -0.204 & -0.166 & 0.127 & -0.048 & -0.121 & -0.125 & -0.066 \\
\hline Num Blockholders & $+/-$ & -0.021 & 0.022 & 0.003 & 0.014 & -0.001 & 0.024 & 0.022 & 0.005 \\
\hline Blockholder Pct & - & -0.024 & -0.450 & -0.253 & -0.162 & 0.032 & -0.500 & -0.381 & -0.189 \\
\hline Employees & $+/-$ & 0.014 & 0.010 & 0.012 & 0.025 & 0.015 & 0.012 & $0.039^{* * * *}$ & 0.016 \\
\hline Leverage & - & 0.035 & 0.150 & 0.096 & 0.065 & -0.091 & 0.120 & -0.120 & 0.072 \\
\hline High Tax & - & -0.065 & -0.049 & -0.040 & -0.075 & -0.056 & -0.058 & 0.017 & -0.032 \\
\hline Low Tax & + & -0.074 & -0.113 & $-0.239 * *$ & $-0.198^{* *}$ & $-0.230^{* * *}$ & -0.120 & -0.089 & $-0.230^{*}$ \\
\hline Cash Flow/Employee & - & 0.001 & $0.001^{* *}$ & $0.0008 \#$ & 0.0007 & 0.0004 & $0.0011^{*}$ & 0.0005 & 0.0006 \\
\hline Cash Level/Employee & - & 0.0003 & $0.0009 * * *$ & $0.0009 * * *$ & $0.0008^{* * *}$ & $0.0009 * * *$ & $0.0010^{* * *}$ & $0.0006^{* * *}$ & $0.0007^{* *}$ \\
\hline Employee Growth & + & -0.108 & -0.102 & -0.094 & -0.169 & $-0.105^{*}$ & -0.093 & -0.047 & -0.131 \\
\hline West Location & $+/-$ & -0.033 & 0.013 & 0.023 & -0.012 & -0.074 & 0.012 & 0.046 & -0.021 \\
\hline East Location & $+/-$ & -0.016 & 0.013 & -0.0009 & 0.0009 & 0.015 & 0.006 & 0.001 & -0.047 \\
\hline Attraction Objective & + & 0.0001 & 0.0001 & 0.0002 & 0.0004 & 0.0007 & 0.0001 & -0.0004 & 0.0007 \\
\hline Retention Objective & + & $0.0004^{* *}$ & $0.0035^{* *}$ & $0.0030^{* *}$ & $0.0025^{*}$ & 0.0006 & $0.0031^{* *}$ & 0.0001 & $0.0034^{* *}$ \\
\hline YR2000 & & 0.024 & -0.001 & -0.004 & 0.025 & -0.024 & -0.006 & 0.039 & 0.047 \\
\hline $\mathrm{N}$ & & 79 & 85 & 86 & 81 & 53 & 88 & 97 & 73 \\
\hline Adjusted $\mathrm{R}^{2}$ & & -0.036 & 0.137 & 0.278 & 0.198 & 0.478 & 0.207 & 0.270 & 0.226 \\
\hline F-Statistic & & 0.851 & 1.741 & 2.822 & 2.098 & 3.644 & 2.279 & 2.976 & 2.171 \\
\hline p-value & & 0.636 & 0.054 & 0.001 & 0.009 & 0.001 & 0.008 & 0.000 & 0.015 \\
\hline
\end{tabular}

Statistically significant at the $0.15,0.10,0.05,0.01$ levels (two-tailed), respectively. See Appendix A for variable definitions. 
Table 9

Analysis of Return on Assets Two Years After the Grant of Equity-Based Incentives in New Economy Firms

Regression Model: $R O A_{t}=\beta_{0}+\beta_{l}$ GrantResidual ${ }^{+}+\beta_{2}$ Grant Residual $+\beta_{3}$ Equity Residual ${ }^{+}+\beta_{4}$

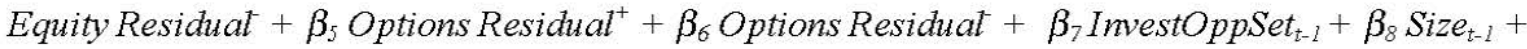
$\beta_{9}$ Volatility $_{t-1}+\beta_{10} R O A_{t-1}++\beta_{11}$ Year 2000 indicator + Industry indicators $+\varepsilon_{t}$.

Panel A: Equity Grants Across Hierarchical Levels

\begin{tabular}{|c|c|c|c|c|c|c|}
\hline & $\begin{array}{c}\text { Chief } \\
\text { Executive } \\
\text { Officer }\end{array}$ & $\begin{array}{c}\text { Vice } \\
\text { President }\end{array}$ & Director & Manager & $\begin{array}{c}\text { Individual } \\
\text { Contributor }\end{array}$ & $\begin{array}{c}\text { Non- } \\
\text { Exempt }\end{array}$ \\
\hline Intercept & $0.380 * *$ & $0.006 * *$ & 0.1898 & 0.104 & -0.122 & 0.009 \\
\hline Grant Residual $^{+}$ & 0.111 & -0.189 & -0.407 & -0.154 & 0.164 & 0.331 \\
\hline Grant Residual $^{-}$ & $0.659 *$ & 0.298 & $1.071 * *$ & 0.044 & 0.227 & -0.430 \\
\hline Equity Residual $^{+}$ & 0.115 & 0.242 & 0.366 & 0.318 & 0.296 & 0.283 \\
\hline Equity Residual $^{-}$ & -0.125 & -0.212 & $-0.624 * *$ & -0.201 & -0.217 & -0.357 \\
\hline Options Residual $^{+}$ & 0.070 & $0.525 \#$ & 0.345 & $0.416 \#$ & $0.504 \#$ & $0.644 *$ \\
\hline Options Residual ${ }^{-}$ & 0.492 **** & $0.360 \#$ & $0.506 * *$ & $0.463 * *$ & 0.312 & $0.414 *$ \\
\hline InvestOppSet & 0.015 & -0.004 & 0.003 & -0.016 & -0.002 & -0.008 \\
\hline Size & -0.002 & $0.027 \#$ & 0.018 & 0.008 & 0.030 & 0.009 \\
\hline Volatility & $-0.903^{* * *}$ & -0.204 & -0.484 & -0.0233 & -0.015 & 0.172 \\
\hline Past ROA & $0.327 * *$ & $0.491 * *$ & $0.567 * * *$ & $0.299 *$ & $0.461 * *$ & $0.512 * *$ \\
\hline COMPUTER & $-0.238 * * *$ & $-0.277 * *$ & $-0.352 * *$ & $-0.170 \#$ & $-0.233 \#$ & $-0.287^{* *} *$ \\
\hline SOFTWARE & -0.106 & $-0.225 *$ & $-0.220^{*}$ & -0.068 & -0.167 & -0.147 \\
\hline SEMICON & -0.106 & $-0.243 * *$ & $-0.278 * *$ & $-0.203 * *$ & -0.189 & $-0.269 * *$ \\
\hline TELECOM & $-0.199 * *$ & $-0.233 \#$ & -0.197 & -0.149 & -0.171 & -0.138 \\
\hline NETWORK & $-0.170 \#$ & $-0.287^{*}$ & $-0.266^{*}$ & $-0.206 \#$ & -0.216 & $-0.309 \#$ \\
\hline INTERNET & -0.076 & -0.064 & -0.248 & 0.000 & -0.217 & $-0.353 *$ \\
\hline YR2000 & $0.063 \#$ & 0.005 & 0.028 & -0.002 & -0.001 & 0.011 \\
\hline $\mathrm{N}$ & 63 & 78 & 70 & 59 & 72 & 68 \\
\hline Adjusted $\mathrm{R}^{2}$ & 0.458 & 0.214 & 0.303 & 0.322 & 0.142 & 0.204 \\
\hline F-Statistic & 4.079 & 2.236 & 2.766 & 2.721 & 1.689 & 2.008 \\
\hline p-value & 0.000 & 0.012 & 0.003 & 0.005 & 0.074 & 0.029 \\
\hline
\end{tabular}


Table 9 (continued)

Panel B: Equity Grants Across Functional Areas

\begin{tabular}{|c|c|c|c|}
\hline & Technical & $\begin{array}{c}\text { Non- } \\
\text { Technical }\end{array}$ & Sales \\
\hline Intercept & 0.284 & 0.129 & 0.206 \\
\hline Grant Residual $^{+}$ & $-0.551 \#$ & -0.184 & 0.128 \\
\hline Grant Residual $^{-}$ & 1.357 **** & $0.793 \#$ & -0.302 \\
\hline Equity Residual $^{+}$ & 0.292 & 0.315 & 0.317 \\
\hline Equity Residual' & $-0.543 * *$ & $-0.532 *$ & -0.160 \\
\hline Options Residual $^{+}$ & 0.247 & 0.354 & $0.566 \#$ \\
\hline Options Residual ${ }^{-}$ & $0.482 * *$ & $0.477 *$ & $0.511 * *$ \\
\hline InvestOppSet & 0.006 & 0.003 & -0.000 \\
\hline Size & 0.009 & 0.015 & 0.000 \\
\hline Volatility & -0.437 & -0.469 & -0.598 \\
\hline Past ROA & $0.577 * * * *$ & $0.565 * * *$ & 0.550 **** \\
\hline COMPUTER & $-0.362 * * *$ & $-0.272 *$ & $-0.283^{* * *}$ \\
\hline SOFTWARE & $-0.220 * *$ & -0.146 & -0.129 \\
\hline SEMICON & $-0.272 * *$ & $-0.217 \#$ & $-0.245 * *$ \\
\hline TELECOM & $-0.203 \#$ & -0.133 & -0.171 \\
\hline NETWORK & $-0.236 \#$ & -0.230 & $-0.236 \#$ \\
\hline INTERNET & -0.121 & -0.219 & 0.000 \\
\hline YR2000 & 0.051 & 0.017 & 0.030 \\
\hline $\mathrm{N}$ & 74 & 70 & 59 \\
\hline Adjusted $\mathrm{R}^{2}$ & 0.339 & 0.258 & 0.310 \\
\hline F-Statistic & 3.198 & 2.413 & 2.628 \\
\hline p-value & 0.001 & 0.008 & 0.006 \\
\hline
\end{tabular}




\section{Notes to Table 9}

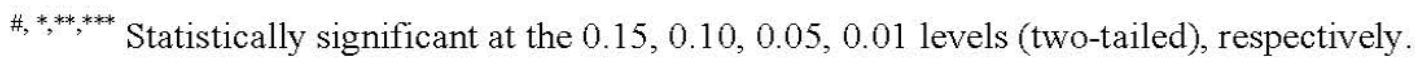

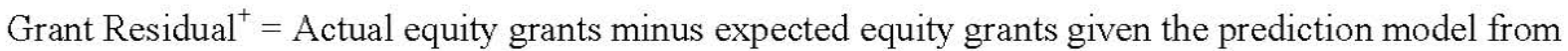
Tables 5 or 6 , if the difference is $>0$, and 0 otherwise.

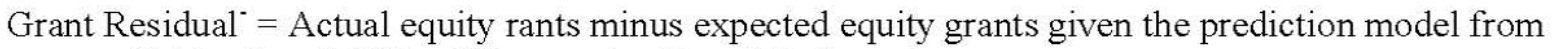
Tables 5 or 6 , if the difference is $<0$, and 0 otherwise.

Equity Residual $^{+}=$Actual equity holdings (scaled by ten times salary) by top five executives in the year prior to the grant minus expected equity holdings (see section 5.4), if the difference is $>0$, and 0 otherwise.

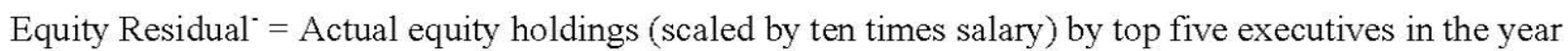
prior to the grant minus expected equity holdings (see section 5.4 ), if the difference is $<0$, and 0 otherwise.

Options Residual ${ }^{+}=$Actual options holdings (scaled by ten times salary) by top five executives in the year prior to the grant minus expected options holdings (see section 5.4), if the difference is $>0$, and 0 otherwise.

Options Residual ${ }^{-}=$Actual options holdings (scaled by ten times salary) by top five executives in the year prior to the grant minus expected options holdings (see section 5.4), if the difference is $<0$, and 0 otherwise.

InvestOppSe $t=$ Average of the standardized scores for Book/Market, R\&D/Sales, Adv/Sales, Sales Growth, and natural logarithm of company age (years since IPO) in the year prior to the equity grant. Book/Market and natural logarithm of company age are reverse coded.

Size $=$ Natural logarithm of the sum of market value of equity and the book value of long-term debt in the year prior to equity grant.

Volatility $=$ Standard deviation of continuous compounded monthly returns during the year prior to equity grant.

COMPUTER, SOFTWARE, SEMICON, TELECON, NETWORK, AND INTERNET = Indicators variable that equal one if the firm reports that it belongs to this industry, and zero otherwise.

YR2000 = Indicator variable equal to one if the survey was conducted during calendar year 2000, and zero otherwise. 
Table 10

Analysis of 24-Month Subsequent Stock Price Performance Associated With Equity-Based Incentives in New Economy Firms

Regression Model: RETURN $_{t}=\beta_{0}+\beta_{l}$ Grant Residual $^{+}+\beta_{2}$ Grant Residual $^{+} \beta_{3}$ Equity Residual $^{+}+$

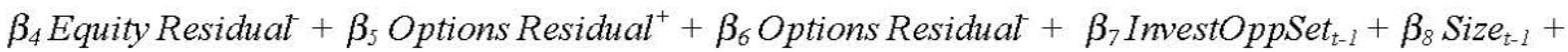
$\beta_{9}$ Volatility $_{t-1}+\beta_{10} R O A_{t-1}++\beta_{11}$ Year 2000 indicator + Industry indicators $+\varepsilon_{t}$.

Panel A: Equity Grants Across Hierarchical Levels

\begin{tabular}{|c|c|c|c|c|c|c|}
\hline & $\begin{array}{c}\text { Chief } \\
\text { Executive } \\
\text { Officer }\end{array}$ & $\begin{array}{c}\text { Vice } \\
\text { President }\end{array}$ & Director & Manager & $\begin{array}{c}\text { Individual } \\
\text { Contributor }\end{array}$ & $\begin{array}{c}\text { Non- } \\
\text { Exempt }\end{array}$ \\
\hline Intercept & 0.143 **** & $0.069 *$ & 0.052 & 0.069 & $0.072 \#$ & $0.076^{*}$ \\
\hline Grant Residual $^{+}$ & 0.029 & -0.004 & -0.017 & -0.050 & -0.058 & $0.271 * *$ \\
\hline Grant Residual $^{-}$ & 0.026 & 0.068 & 0.087 & 0.088 & $0.151 *$ & -0.033 \\
\hline Equity Residual $^{+}$ & 0.054 & 0.008 & 0.043 & 0.042 & 0.031 & -0.024 \\
\hline Equity Residual- & $-0.085 \#$ & $-0.101 *$ & $-0.135 * *$ & $-0.117 *$ & $-0.110 *$ & -0.048 \\
\hline Options Residual $^{+}$ & 0.010 & 0.049 & 0.035 & 0.056 & 0.044 & 0.039 \\
\hline Options Residual ${ }^{-}$ & $0.123 * *$ & $0.088 * *$ & $0.101 *$ & $0.077 \#$ & $0.078 *$ & $0.084 *$ \\
\hline InvestOppSet & $0.008 * *$ & 0.000 & 0.001 & 0.001 & 0.001 & -0.001 \\
\hline Size & -0.003 & 0.001 & 0.002 & 0.000 & 0.002 & -0.001 \\
\hline Volatility & $-0.228 *$ & -0.109 & -0.112 & -0.088 & $-0.161 \#$ & -0.115 \\
\hline COMPUTER & $-0.045 *$ & $-0.039 *$ & -0.032 & $-0.039 \#$ & $-0.038 \#$ & $-0.044 * *$ \\
\hline SOFTWARE & -0.049 & $-0.038 *$ & -0.029 & -0.031 & $-0.038 *$ & -0.030 \\
\hline SEMICON & -0.012 & -0.010 & 0.002 & -0.009 & -0.011 & -0.005 \\
\hline TELECOM & $-0.045 \#$ & $-0.042 \#$ & -0.024 & -0.026 & $-0.044 \#$ & -0.031 \\
\hline NETWORK & -0.036 & -0.035 & -0.021 & -0.031 & -0.033 & -0.010 \\
\hline INTERNET & $-0.059 *$ & -0.017 & -0.021 & 0.000 & -0.034 & $-0.059 \#$ \\
\hline Year 2000 & -0.013 & $-0.024 * *$ & $-0.021 *$ & $-0.022 \#$ & $-0.020 *$ & $-0.028 * *$ \\
\hline $\mathrm{N}$ & 66 & 79 & 72 & 62 & 73 & 70 \\
\hline Adjusted $\mathrm{R}^{2}$ & 0.238 & 0.217 & 0.160 & 0.123 & 0.228 & 0.270 \\
\hline F-Statistic & 2.268 & 2.350 & 1.847 & 1.571 & 2.329 & 2.593 \\
\hline p-value & 0.014 & 0.009 & 0.048 & 0.012 & 0.010 & 0.005 \\
\hline
\end{tabular}


Table 10 (continued)

Panel B: Equity Grants Across Functional Areas

\begin{tabular}{|c|c|c|c|}
\hline & Technical & $\begin{array}{c}\text { Non- } \\
\text { Technical }\end{array}$ & Sales \\
\hline Intercept & 0.067 & $0.081 \#$ & 0.063 \\
\hline Residual $^{+}$ & -0.019 & 0.010 & -0.069 \\
\hline Residual $^{-}$ & 0.090 & 0.104 & 0.076 \\
\hline Equity Residual $^{+}$ & 0.023 & 0.025 & 0.052 \\
\hline Equity Residual ${ }^{-}$ & $-0.125 * *$ & $-0.132 * *$ & $-0.105 \#$ \\
\hline Options Residual $^{+}$ & 0.031 & 0.017 & 0.066 \\
\hline Options Residual & $0.088 *$ & $0.106 * *$ & 0.065 \\
\hline InvestOppSet & 0.000 & 0.002 & 0.001 \\
\hline Size & 0.001 & 0.000 & 0.000 \\
\hline Volatility & -0.118 & $-0.197 \#$ & -0.109 \\
\hline COMPUTER & $-0.040 \#$ & -0.030 & -0.037 \\
\hline SOFTWARE & $-0.037^{*}$ & -0.027 & -0.032 \\
\hline SEMICON & -0.008 & 0.007 & -0.011 \\
\hline TELECOM & -0.034 & -0.020 & -0.024 \\
\hline NETWORK & -0.028 & -0.017 & -0.033 \\
\hline INTERNET & -0.030 & -0.020 & 0.000 \\
\hline Year 2000 & $-0.020 *$ & $-0.024 * *$ & -0.020 \\
\hline $\mathrm{N}$ & 76 & 72 & 60 \\
\hline Adjusted $\mathrm{R}^{2}$ & 0.164 & 0.214 & 0.088 \\
\hline F-Statistic & 1.919 & 2.208 & 1.378 \\
\hline p-value & 0.036 & 0.015 & 0.201 \\
\hline
\end{tabular}




\section{Notes to Table 10}

$\#, *, * *, * * *$ Statistically significant at the $0.15,0.10,0.05,0.01$ levels (two-tailed), respectively.

Grant Residual $^{+}=$Actual equity grants minus expected equity grants given the prediction model from Tables 5 or 6 , if the difference is $>0$, and 0 otherwise.

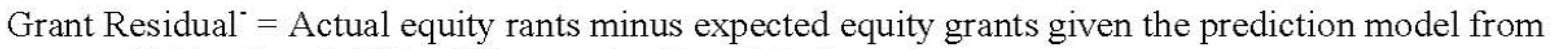
Tables 5 or 6 , if the difference is $<0$, and 0 otherwise.

Equity Residual $^{+}=$Actual equity holdings (scaled by ten times salary) by top five executives in the year prior to the grant minus expected equity holdings (see section 5.4), if the difference is $>0$, and 0 otherwise.

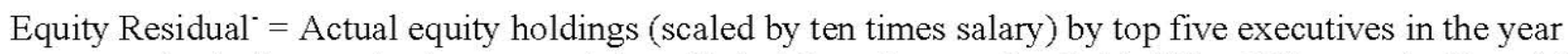
prior to the grant minus expected equity holdings (see section 5.4 ), if the difference is $<0$, and 0 otherwise.

Options Residual ${ }^{+}=$Actual options holdings (scaled by ten times salary) by top five executives in the year prior to the grant minus expected options holdings (see section 5.4 ), if the difference is $>0$, and 0 otherwise.

Options Residual ${ }^{-}=$Actual options holdings (scaled by ten times salary) by top five executives in the year prior to the grant minus expected options holdings (see section 5.4 ), if the difference is $<0$, and 0 otherwise.

InvestOppSe $t=$ Average of the standardized scores for Book/Market, R\&D/Sales, Adv/Sales, Sales Growth, and natural logarithm of company age (years since IPO) in the year prior to the equity grant. Book/Market and natural logarithm of company age are reverse coded.

Size $=$ Natural logarithm of the sum of market value of equity and the book value of long-term debt in the year prior to equity grant.

Volatility $=$ Standard deviation of continuous compounded monthly returns during the year prior to equity grant.

COMPUTER, SOFTWARE, SEMICON, TELECON, NETWORK, AND INTERNET = Indicators variable that equal one if the firm reports that it belongs to this industry, and zero otherwise.

YR2000 =Indicator variable equal to one if the survey was conducted during calendar year 2000, and zero otherwise. 